OPEN ACCESS

Edited by: David Emerson,

Bigelow Laboratory for Ocean Sciences, USA

Reviewed by:

John Senko,

The University of Akron, USA

Eric Roden,

University of Wisconsin-Madison,

USA

*Correspondence: Jens Kallmeyer

kallm@gfz-potsdam.de

${ }^{\dagger}$ These authors have contributed equally to this work.

Specialty section: This article was submitted to Microbiological Chemistry and Geomicrobiology, a section of the journa

Frontiers in Microbiology

Received: 03 March 2016 Accepted: 13 June 2016

Published: 30 June 2016

Citation:

Vuillemin A, Friese A, Alawi M, Henny C, Nomosatryo S, Wagner D, Crowe SA and Kallmeyer J (2016) Geomicrobiological Features of Ferruginous Sediments from Lake Towuti, Indonesia.

Front. Microbiol. 7:1007. doi: 10.3389/fmicb.2016.01007

\section{Geomicrobiological Features of Ferruginous Sediments from Lake Towuti, Indonesia}

\author{
Aurèle Vuillemin ${ }^{1 \dagger}$, André Friese ${ }^{1 t}$, Mashal Alawi ${ }^{1}$, Cynthia Henny ${ }^{2}$, Sulung Nomosatryo ${ }^{2}$, \\ Dirk Wagner ${ }^{1}$, Sean A. Crowe ${ }^{3,4}$ and Jens Kallmeyer ${ }^{1 *}$ \\ ${ }^{1}$ GFZ German Research Centre for Geosciences, Helmholtz Centre Potsdam, Section 5.3 Geomicrobiology, Potsdam, \\ Germany, ${ }^{2}$ Research Center for Limnology, Indonesian Institute of Sciences, Cibinong, Indonesia, ${ }^{3}$ Department of \\ Microbiology and Immunology, University of British Columbia, Vancouver, BC, Canada, ${ }^{4}$ Department of Earth, Ocean, \\ and Atmospheric Sciences, University of British Columbia, Vancouver, BC, Canada
}

Lake Towuti is a tectonic basin, surrounded by ultramafic rocks. Lateritic soils form through weathering and deliver abundant iron (oxy)hydroxides but very little sulfate to the lake and its sediment. To characterize the sediment biogeochemistry, we collected cores at three sites with increasing water depth and decreasing bottom water oxygen concentrations. Microbial cell densities were highest at the shallow site-a feature we attribute to the availability of labile organic matter (OM) and the higher abundance of electron acceptors due to oxic bottom water conditions. At the two other sites, OM degradation and reduction processes below the oxycline led to partial electron acceptor depletion. Genetic information preserved in the sediment as extracellular DNA (eDNA) provided information on aerobic and anaerobic heterotrophs related to Nitrospirae, Chloroflexi, and Thermoplasmatales. These taxa apparently played a significant role in the degradation of sinking OM. However, eDNA concentrations rapidly decreased with core depth. Despite very low sulfate concentrations, sulfate-reducing bacteria were present and viable in sediments at all three sites, as confirmed by measurement of potential sulfate reduction rates. Microbial community fingerprinting supported the presence of taxa related to Deltaproteobacteria and Firmicutes with demonstrated capacity for iron and sulfate reduction. Concomitantly, sequences of Ruminococcaceae, Clostridiales, and Methanomicrobiales indicated potential for fermentative hydrogen and methane production. Such first insights into ferruginous sediments showed that microbial populations perform successive metabolisms related to sulfur, iron, and methane. In theory, iron reduction could reoxidize reduced sulfur compounds and desorb OM from iron minerals to allow remineralization to methane. Overall, we found that biogeochemical processes in the sediments can be linked to redox differences in the bottom waters of the three sites, like oxidant concentrations and the supply of labile $\mathrm{OM}$. At the scale of the lacustrine record, our geomicrobiological study should provide a means to link the extant subsurface biosphere to past environments.

Keywords: bottom waters, iron-rich sediment, sedimentary microbes, extracellular DNA, sulfate reduction, iron reduction, Lake Towuti 


\section{INTRODUCTION}

Lake Towuti is a tropical $200 \mathrm{~m}$ deep tectonic lake seated in ophiolitic rocks and surrounded by lateritic soils (Lehmusluoto et al., 1995; Russell and Bijaksana, 2012). It is part of the Malili Lakes system, comprising several interconnected lakes, including Lake Matano, the 10th deepest lake in the world $(\sim 600 \mathrm{~m})$. Its location on Sulawesi, Indonesia (Figure 1A) renders Lake Towuti's sediments prime recorders of paleoclimatic changes in the tropical Western Pacific warm pool (Russell et al., 2014). The tropical climate and the lateritic weathering of the (ultra)mafic catchment of the Malili Lakes system (Figure 1B) cause a strong flux of iron to the lake. Surrounding lateritic soils are typically related to limonite types, with mostly goethite $(\alpha-\mathrm{FeOOH})$ and ferrihydrite $\left(\mathrm{Fe}_{2} \mathrm{O}_{3} \cdot 0.5 \mathrm{H}_{2} \mathrm{O}\right)$ transported to the basin (Crowe et al., 2004; Golightly, 2010) as well as some hematite $\left(\mathrm{Fe}_{2} \mathrm{O}_{3}\right)$ and detrital magnetite $\left(\mathrm{Fe}_{3} \mathrm{O}_{4}\right)$. High iron fluxes to the lake may exert a decisive constraint on bioavailable phosphorus in the epilimnion as it is scavenged by iron (hydr)oxides, likely driving Lake Towuti's water column toward severely nutrient-limited conditions. However, anoxia in stratified water column can lead to iron reduction and partial release of adsorbed $\mathrm{P}$ into the water at the oxycline and below (Zegeye et al., 2012). Biogeochemical and microbiological data gathered from nearby Lake Matano reveal persistent anoxia in the deeper part of Lake Matano's water column (Crowe et al., 2008b; Jones et al., 2011) with organic matter (OM) degradation through methanogenesis (Katsev et al., 2010; Crowe et al., 2011). Although Lake Towuti is anoxic at greater depths as well, it is less deep and can mix periodically
(Haffner et al., 2001), presumably causing transient bottom water oxygenation (Costa et al., 2015).

Once buried, ferruginous sediments likely support microbial communities, which can utilize a range of metalliferous substrates (Crowe et al., 2007). Although microbial activity decreases dramatically below the water-sediment interface and with increasing sediment depth (Kallmeyer et al., 2012), even this low activity can have an appreciable impact on both sediment composition and biogeochemical cycles over long-time periods (Berner, 1980; Freudenthal et al., 2001; Horsfield and Kieft, 2007). In addition, iron minerals are also suspected to strongly adsorb DNA (Cecchio et al., 2005; He et al., 2008). Upon cell lysis, nucleic acids are released into the surrounding water and sediment and partitioned between sorption to reactive Fe surfaces (Pietramellara et al., 2008; Ceccherini et al., 2009) and uptake or degradation via microbial metabolisms (Corinaldesi et al., 2007, 2008). Binding to metal oxides and colloids (Ceccherini et al., 2009; Cleaves et al., 2011) could result in preservation and persistence of extracellular DNA (eDNA) in the lacustrine record (Pietramellara et al., 2008), providing a valuable archive of genetic information (Corinaldesi et al., 2011). However, since metal-reducing bacteria have the capacity to solubilize structural Fe and utilize adsorbed nutrients (Dong et al., 2003; Crowe et al., 2007), the sediment-bound eDNA should not be totally recalcitrant (Baldwin, 2013 and references therein) and could serve as a labile organic substrate for sedimentary microbes (Corinaldesi et al., 2007). Its concentrations should then depend on the complex interplay between these processes (Dell'Anno and Corinaldesi, 2004). Altogether, Lake Towuti

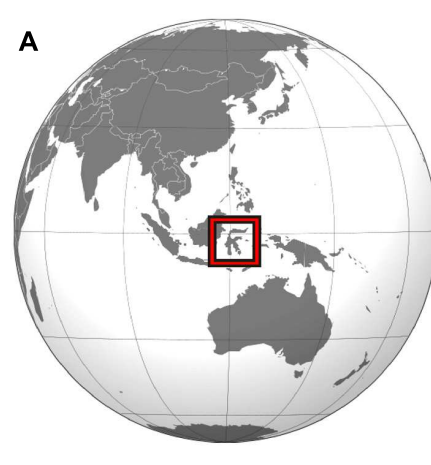

B

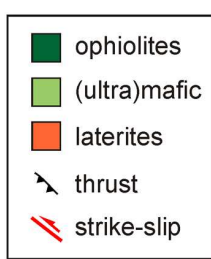

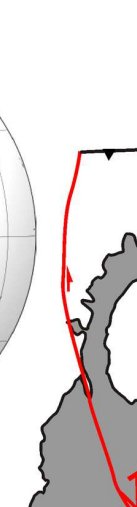

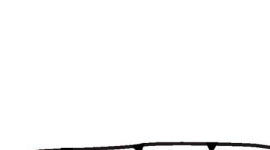

C

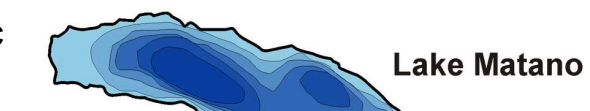
Lake Matano

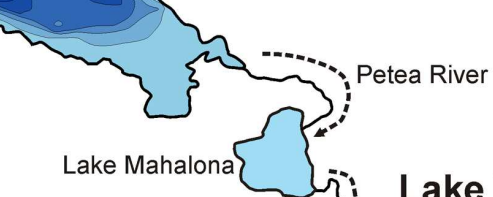

Sulawesi

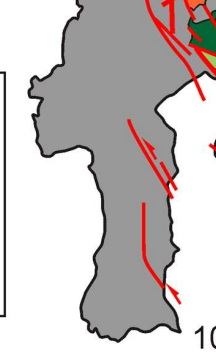

,
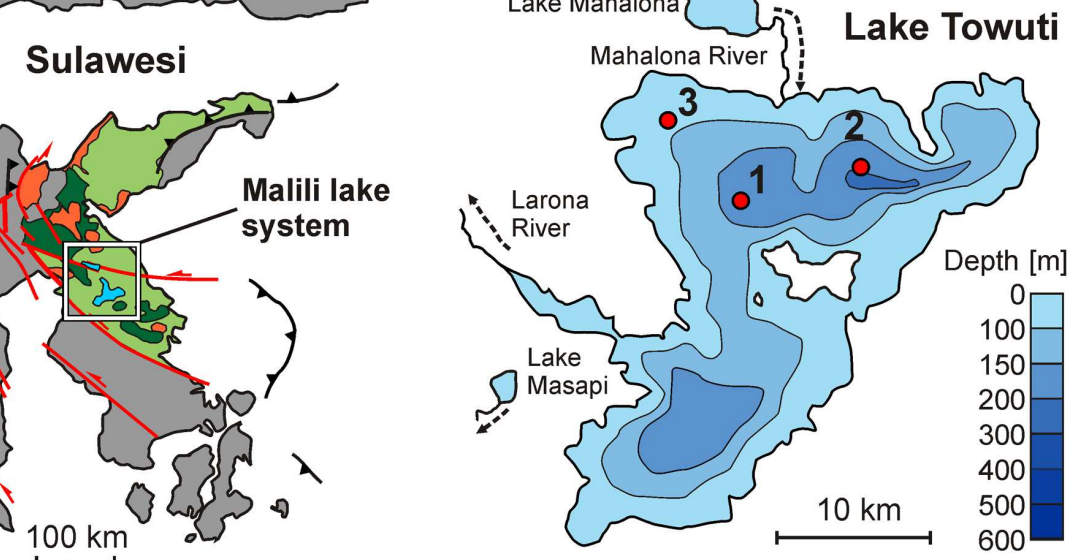

FIGURE 1 | Lake Towuti location and settings. (A) Map of Asia and Oceania displaying the location of Sulawesi Island. (B) Map of Sulawesi illustrating the geological context of the Malili lake system (modified after Calvert and Hall, 2007). (C) Bathymetric map of Lake Matano and Lake Towuti (modified after Herder et al., 2006) displaying the three sites at which gravity cores were retrieved. Sites 1-3 correspond respectively to water depths of 153 , 200 , and 60 m, with oxygenation conditions at the water-sediment interface decreasing with water depth. 
provides the opportunity to examine microbial populations in an iron-dominated and sulfate-poor ecosystem with dynamic redox conditions and infer sorption and diagenetic processes arising from subsurface microbial activity.

In order to investigate the relationship between biogeochemistry and microbial processes in these iron-rich anoxic sediments, we retrieved short sediment cores from Lake Towuti in 2013 and 2014 at three different depths (Figure 1C). The sediment was analyzed for pore water geochemistry, total cell counts and potential sulfate reduction rates (SRR) as well as eDNA and intracellular DNA (iDNA). These data provide a background for geomicrobiological and biogeochemical analysis of the long $(>100 \mathrm{~m})$ drill cores that were retrieved during the ICDP (International Continental Scientific Drilling Program) Towuti drilling campaign in spring/summer 2015.

\section{MATERIALS AND METHODS}

\section{Site Description}

Lake Towuti $\left(2.5^{\circ} \mathrm{S}, 121^{\circ} \mathrm{E}\right)$ is the largest lake within the Malili Lake System, a chain of five tectonic lakes in Sulawesi, Indonesia (Lehmusluoto et al., 1995). It has a surface area of $560 \mathrm{~km}^{2}$ and a maximum water depth of $203 \mathrm{~m}$ (Haffner et al., 2001). Lake Towuti has a tropical humid climate, with an annual average air temperature of $26^{\circ} \mathrm{C}$ and little variations in monthly temperatures. Precipitation averages $2540 \mathrm{~mm}_{\text {year }}{ }^{-1}$, with no distinct dry season (Aldrian and Susanto, 2003). The Mahalona River, which is the main inflow to the north, drains the extensive catchments of Lakes Matano and Mahalona, while the Larona River constitutes the only outflow to the west (Figure 1C). Lake Towuti is weakly conductive $\left(210 \mu \mathrm{S} \mathrm{cm}^{-1}\right)$ and circumneutral ( $\mathrm{pH} \sim 7.8$ ) with a chemistry dominated by $\mathrm{Mg}$ and $\mathrm{HCO}_{3}{ }^{-}$ (Lehmusluoto et al., 1995). Surface water temperatures are commonly $28-29^{\circ} \mathrm{C}$, with weak thermal stratification of the water column (i.e., $28-31^{\circ} \mathrm{C}$; Figure 2). Unlike upstream Lake Matano, which is permanently stratified and anoxic below $110 \mathrm{~m}$ water depth due to its great depth $(600 \mathrm{~m})$ and steep slopes (Crowe et al., 2008b; Katsev et al., 2010), the entire water column of Lake Towuti is reported to mix at least occasionally (Haffner et al., 2001; Costa et al., 2015). Lake Towuti is usually oxygendepleted below $130 \mathrm{~m}$ depth (Figure 2). As a result of sedimentary $\mathrm{P}$ trapping due to large amounts of iron oxides derived from lateritic soils being transported into the basin (Zegeye et al., 2012), productivity in the water column is expected to be limited (Bramburger et al., 2008).

\section{Sample Processing}

Water temperature, oxygen concentration, light fluorescence reemitted by chlorophyll a (Leeuw et al., 2013), and light transmission profiles were collected on site using a submersible conductivity-temperature-depth probe (CTD; Sea-Bird, SBE-19; Sea-Bird Electronics, Bellevue, WA, USA). Temperature profiles showed that the water column of Lake Towuti is indeed weakly stratified while oxygen concentrations indicated that the watersediment interface at the bottom of Lake Towuti is variably oxygenated depending on water depth, with anoxia in waters below $130 \mathrm{~m}$ (Figure 2). Several sediment cores $(<0.5 \mathrm{~m})$ estimated to cover ca. 1750 years of sedimentation history (Tamuntuan et al., 2015; Vogel et al., 2015) were retrieved at three sites with increasing water depth (60, 153, and $200 \mathrm{~m}$; Figure 1C) and different oxidation states in overlying waters (Figure 2), the intermediate site (153 $\mathrm{m}$ depth) was chosen to be the main site of the ICDP Towuti Drilling Project. The cores were sampled for pore water geochemistry, total cell counts, potential SRR and small subunit (16S) rRNA gene fingerprinting analyses.

Pore water sampling was carried out on site under anoxic conditions, using a glove bag flushed with nitrogen gas in order to prevent oxidation of the sediment. Using an aseptic spatula, we sectioned the sediment cores in $0.5,1$, and $2 \mathrm{~cm}$ resolution for the upper $1,1-10$, and below $10 \mathrm{~cm}$, respectively. Sediment samples were transferred into $50 \mathrm{~mL}$ centrifuge tubes and Rhizon Pore Water Samplers (Rhizon CSS, Rhizosphere research products, Dolderstraat, Netherlands) were inserted into the sediment through a hole in the lid. For each depth interval, $10 \mathrm{~mL}$ of pore water was collected in syringes, filtered through $0.2 \mu \mathrm{m}$ pore size cellulose acetate membrane syringe filters (Minisart, Sartorius Stedim Biotech) to remove all particles and most microorganisms, transferred into $2 \mathrm{~mL}$ twist top vials and stored at room temperature for analysis in the home lab.

Samples for total cell counts were preserved in a $0.2 \mu \mathrm{m}$ filtered fixative solution of lake water amended with formalin (final concentration 2\%). For each sample, $2 \mathrm{~cm}^{3}$ of sediment was retrieved with a sterile $3 \mathrm{~mL}$ cut-off syringe, placed in $15 \mathrm{~mL}$ centrifuge tube filled with $8 \mathrm{~mL}$ of fixative solution and shaken for complete homogenization. The tubes were sealed and stored at $4^{\circ} \mathrm{C}$ until analysis in the home lab.

For nucleic acid analyses, entire short cores were sampled inside the nitrogen-filled glove bag. Using an aseptic spatula, we sectioned the cores into 1,2 , and $5 \mathrm{~cm}$ intervals for the first $10 \mathrm{~cm}$, between 10 and $20 \mathrm{~cm}$ and below $20 \mathrm{~cm}$ depth, respectively. Samples were packed into gas-tight aluminum foil bags, flushed with nitrogen gas and heat-sealed to keep them under anoxic conditions. Until DNA extraction in the home lab the samples were stored at room temperature. Since lake temperatures are ca. $28^{\circ} \mathrm{C}$ throughout the year, we considered this storage appropriate to minimize cell lysis or potential shifts in the microbial assemblage due to refrigeration. Freezing was not an option as it would cause cell lysis and therefore artificially increase the eDNA pool.

Samples for potential SRR measurements were collected in triplicate using glass barrels with approximately $5 \mathrm{~cm}^{3}$ volume. The glass barrels were used to retrieve small sub-cores from the undisturbed inner part of the core, sealed with a butyl rubber stopper and stored in sealed, nitrogen-flushed gas-tight aluminum foil bags at room temperature until incubation in the home lab.

\section{Laboratory Procedures Total Organic Carbon and Total Nitrogen}

Total nitrogen (TN) and total carbon (TC) were measured, using a Vario EL III CHNOS elemental analyzer (Elementar Analysensysteme, Hanau, Germany). Each sample tin cup was 


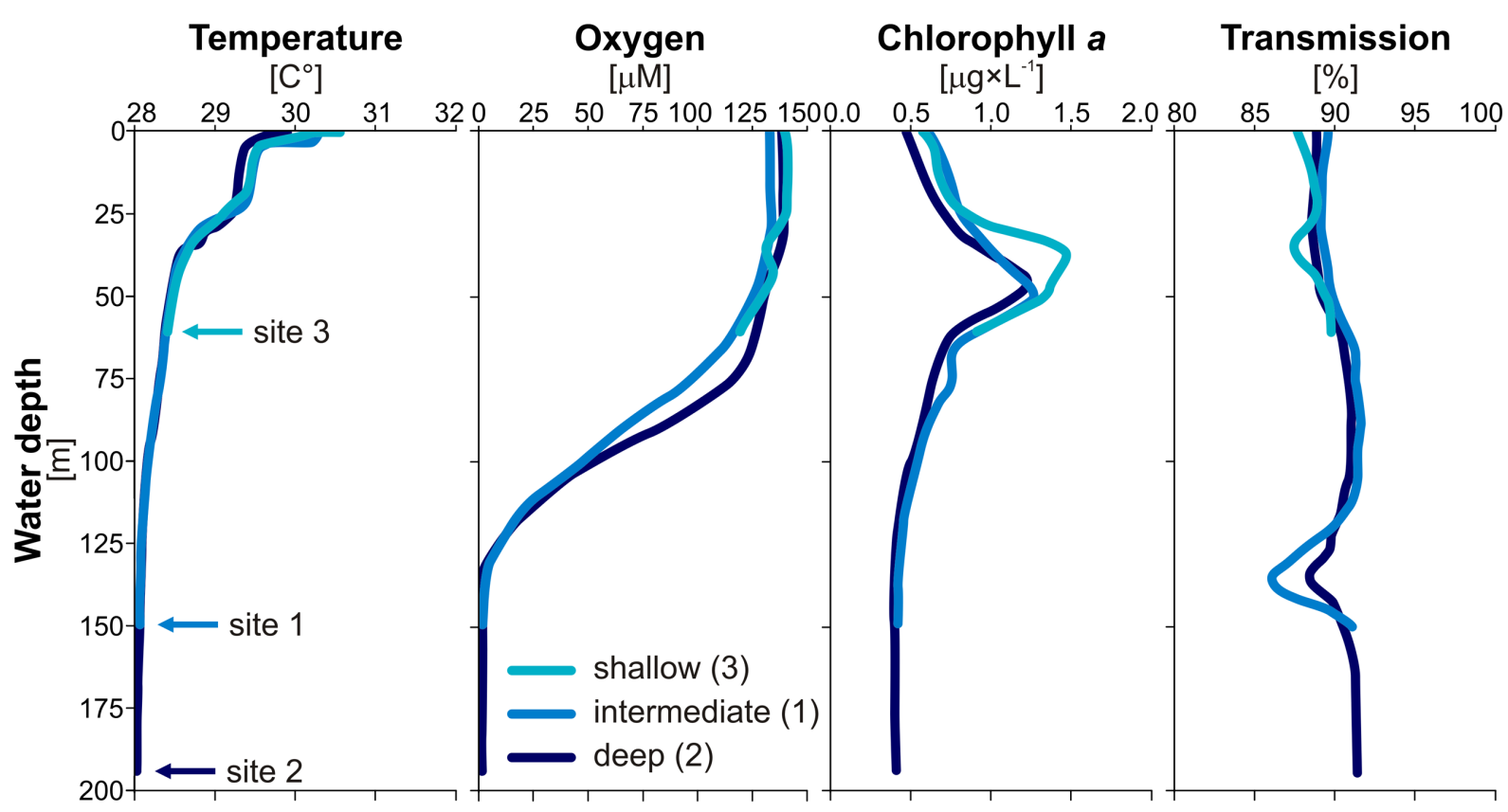

FIGURE 2 | Water column profiles. CTD casts for temperatures $\left({ }^{\circ} \mathrm{C}\right)$, oxygen concentrations $(\mu \mathrm{M})$, chlorophyll a $\left(\mu \mathrm{g} \times \mathrm{L}^{-1}\right)$, and light transmission [\%] measured in the water column of Lake Towuti at each of the three sites. Results show that Lake Towuti is weakly thermally stratified with an oxycline occurring in between 90 and $130 \mathrm{~m}$ depth. Chlorophyll a peaks up at $50 \mathrm{~m}$ depth, while the presence of suspended particles can be inferred from the transmission decrease at $130 \mathrm{~m}$ depth.

loaded with 8-9 mg of freeze-dried, powdered sediment plus a spatula tip of tungsten oxide $\left(\mathrm{WO}_{3}\right)$ to enhance the combustion, and then combusted at $1150^{\circ} \mathrm{C}$. Detection limit is below $0.1 \%$. TC results were used to calibrate volumes of sample required for total organic carbon (TOC) measurements. For TOC analysis, between 30 and $70 \mathrm{mg}$ of sediment powder were loaded into a crucible and burnt at $580^{\circ} \mathrm{C}$ (sensitive carbon $\mathrm{T}^{\circ}$ for non-calcareous samples), 850 and $1150^{\circ} \mathrm{C}$ (intensive carbon $\mathrm{T}^{\circ}$ for calcareous samples) using a Vario MAX cube elemental macro analyzer (Elementar Analysensysteme), equipped with the soliTIC option for the determination of the total organically bound and inorganic carbon in the sample. Pretreatment of samples with $\mathrm{HCl}(5 \%)$, as is normally done for standard elemental analyzers (Byers et al., 1978) is not needed with this device. TOC and TN were recalculated to the content of the whole sample to present results in dry mass \%. TOC and TN values were then corrected by their respective atomic weights (i.e., 14/12) and used to calculate molar $\mathrm{C}_{\text {org }} / \mathrm{N}$ ratios.

\section{Iron Spectrophotometry}

Dissolved iron concentrations in pore water were measured in the field via spectrophotometry (Viollier et al., 2000). Directly after pore water retrieval, we aliquoted $1 \mathrm{~mL}$ of pore water sample to $1.6 \mathrm{~mL}$ Rotilabo single-use cells (Carl Roth, Karlsruhe, Germany) and stabilized dissolved $\mathrm{Fe}^{2+}$ by adding $100 \mu \mathrm{L}$ of Ferrozine Iron Reagent (Sigma-Aldrich Chemie, Munich, Germany). To avoid oxidation during handling, all sample handling was carried out inside the nitrogen-filled glove bag. Absorbance of the colored solution was measured at $562 \mathrm{~nm}$ with a DR 3900 spectrophotometer (Hach, Düsseldorf, Germany). Detection limit of the method is $0.25 \mu \mathrm{M}$.

\section{Ion Chromatography}

Cation and anion concentrations in pore water samples were analyzed using an ion chromatography (IC) system (Sykam Chromatographie, Fürstenfeldbruck, Germany). Injected sample volume was $50 \mu \mathrm{L}$ for both anions and cations. For cations, the IC system consisted of a S5300 sample injector (Sykam), a $4.6 \times 125 \mathrm{~mm}$ Reprosil CAT column (Dr. Maisch HPLC, Ammerbuch-Entringen, Germany) and a S3115 conductivity detector (Sykam). The eluent was $2.5 \mathrm{mM} \mathrm{HNO}_{3}$. Flow rate was set at $1 \mathrm{~mL} \mathrm{~min}{ }^{-1}$ and column oven temperature at $45^{\circ} \mathrm{C}$. A Cation Multi-Element Standard (Carl Roth) was diluted five times for calibration. Based on a respective signal-to-noise $(\mathrm{S} / \mathrm{N})$ ratio of 3 and 10 (Schibler et al., 2007), the detection and quantification limits were calculated for each ion and are as follows: $\mathrm{Li}^{+}(10.5 \mu \mathrm{M} ; 63.5 \mu \mathrm{M}), \mathrm{Na}^{+}(5.8 \mu \mathrm{M} ; 35 \mu \mathrm{M}), \mathrm{K}^{+}$ (9.1 $\mu \mathrm{M} ; 54.7 \mu \mathrm{M}), \mathrm{Mg}^{2+}(9.6 \mu \mathrm{M} ; 44.6 \mu \mathrm{M}), \mathrm{Ca}^{2+}(8.3 \mu \mathrm{M}$; $38.5 \mu \mathrm{M})$ and $\mathrm{NH}_{4}{ }^{+}(11.3 \mu \mathrm{M} ; 67.6 \mu \mathrm{M})$. Samples were measured in triplicates. During each run, nine standards were measured to check for drift. Reproducibility was always better than $5 \%$ for each ion. Concentrations are given as average values based on triplicates, error bars are one standard deviation.

Anions were analyzed by suppressed IC using a SeQuant SAMS anion IC suppressor (EMD Millipore, Billerica, Massachusetts), a S5200 sample injector, a $3.0 \times 250 \mathrm{~mm}$ lithocholic acid (LCA) 14 column and a S3115 conductivity detector (all Sykam). The eluent was $5 \mathrm{mM} \mathrm{Na}_{2} \mathrm{CO}_{3}$ with $20 \mathrm{mg} \mathrm{L}^{-1} 4$-hydroxybenzonitrile and $0.2 \%$ methanol. Flow 


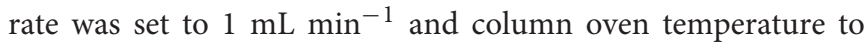
$50^{\circ} \mathrm{C}$. A multi-element anion standard (Sykam) containing $\mathrm{F}^{-}(263.2 \mu \mathrm{M}), \mathrm{Cl}^{-}(564.1 \mu \mathrm{M}), \mathrm{Br}^{-}(250.3 \mu \mathrm{M}), \mathrm{NO}_{2}{ }^{-}$ $(434.7 \mu \mathrm{M}), \mathrm{PO}_{4}{ }^{3-}(210.6 \mu \mathrm{M}), \mathrm{NO}_{3}{ }^{-}(806.4 \mu \mathrm{M})$, and $\mathrm{SO}_{4}{ }^{2-}$ $(520.5 \mu \mathrm{M})$ was diluted 10 times and measured every 10 samples. Respective minimum detection $(\mathrm{S} / \mathrm{N}=3)$ and quantification limits $(\mathrm{S} / \mathrm{N}=10)$ are as follows: $\mathrm{F}^{-}(2.3 \mu \mathrm{M} ; 13.3 \mu \mathrm{M}), \mathrm{Cl}^{-}$ (5.7 $\mu \mathrm{M} ; 16.17 \mu \mathrm{M}), \mathrm{NO}_{2}^{-}(4.1 \mu \mathrm{M} ; 14.14 \mu \mathrm{M}), \mathrm{Br}^{-}(3 \mu \mathrm{M}$; $10.2 \mu \mathrm{M}), \mathrm{NO}_{3}{ }^{-}(2.8 \mu \mathrm{M} ; 9.3 \mu \mathrm{M}), \mathrm{PO}_{4}{ }^{3-}(4.3 \mu \mathrm{M} ; 14.3 \mu \mathrm{M})$ and $\mathrm{SO}_{4}{ }^{2-}(2 \mu \mathrm{M} ; 8.4 \mu \mathrm{M})$. The reproducibility was always better than $3 \%$ for each ion.

For ammonium $\left(\mathrm{NH}_{4}{ }^{+}\right)$concentrations, the cation IC system was converted to a flow injection analysis system (Hall and Aller, 1992) using a second pump and a dialysis cell (Skalar Products, Breda, Netherlands) instead of a separation column. First, $\mathrm{NH}_{4}{ }^{+}$ is quantitatively converted into $\mathrm{NH}_{3}$ by injecting the sample into an alkaline release solution containing $53.75 \mathrm{~g} \mathrm{~L}^{-1}$ citric acid and $70 \mathrm{~g} \mathrm{~L}^{-1}$ sodium hydroxide. The $\mathrm{NH}_{3}$ diffuses through a Teflon membrane into a capture solution made of $1 \mathrm{~g} \mathrm{~L}^{-1}$ boric acid and reacts to form ammonium borate. The associated change in conductivity is measured with a conductivity detector. The flow rate for release and capture solution was 0.1 and $0.3 \mathrm{~mL}$ $\min ^{-1}$, respectively. For $100 \mu \mathrm{L}$ injection volume, the minimum detection $(\mathrm{S} / \mathrm{N}=3)$ and quantification limits $(\mathrm{S} / \mathrm{N}=10)$ are 5 and $12.2 \mu \mathrm{M}$, respectively. Samples were measured in triplicates, the reproducibility was always below $10 \%$.

\section{Potential Sulfate Reduction Rate Quantification}

Potential SRR quantification was performed according to Jørgensen (1978) and Kallmeyer et al. (2004). In brief, $3 \mathrm{kBq}$ of ${ }^{35} \mathrm{SO}_{4}{ }^{2-}$ radiotracer were injected into each sediment plug and incubated for $24 \mathrm{~h}$ in the dark close to situ temperature (ca. $30^{\circ} \mathrm{C}$ ). Incubated sediments were transferred into $10 \mathrm{~mL}$ of $20 \%$ $(\mathrm{w} / \mathrm{v})$ zinc acetate and homogenized to precipitate free sulfide as zinc sulfide and stop microbial activity. The sample slurry was centrifuged $(4000 \times g, 20 \mathrm{~min})$ and $1 \mathrm{~mL}$ of supernatant transferred into a $7 \mathrm{~mL}$ scintillation vial with $4 \mathrm{~mL}$ of Ultima Gold Cocktail (Perkin Elmer, Waltham, MA, USA) for quantification of unreacted ${ }^{35} \mathrm{SO}_{4}{ }^{2-}$. The remaining sediment was flushed out with $20 \mathrm{~mL}$ dimethylformamide into a four-neck glass flask. Non-radioactive zinc sulfide was added as a carrier, followed by injection of $8 \mathrm{~mL}$ of $6 \mathrm{~N} \mathrm{HCl}$ and $16 \mathrm{~mL}$ of $1 \mathrm{M} \mathrm{CrCl}_{2}$ solution and stirring of the sample for $2 \mathrm{~h}$ under a constant flow of nitrogen gas. The released $\mathrm{H}_{2} \mathrm{~S}$ was guided through a trap filled with $7 \mathrm{~mL}$ of $0.1 \mathrm{M}$ of a buffered citric acid/Na-citrate solution to trap ${ }^{35} \mathrm{SO}_{4}{ }^{2-}$-containing aerosols. A second trap filled with $7 \mathrm{~mL}$ of $5 \%(\mathrm{w} / \mathrm{v})$ zinc acetate was used to precipitate $\mathrm{H}_{2} \mathrm{~S}$ as zinc sulfide. At the end of the distillation, the zinc acetate solution was quantitatively transferred into a scintillation vial with $8 \mathrm{~mL}$ of Ultima Gold Cocktail (Perkin Elmer). Radioactivity of radiolabeled sulfide was quantified using a Tri Carb 2500 TR liquid scintillation counter (Packard Instruments, Meriden, CT, USA).

\section{Total Cell Counts}

Cell counts were performed using a modification of the procedure of Kallmeyer et al. (2008). In brief, $50 \mu \mathrm{L}$ of sediment slurry were mixed with $50 \mu \mathrm{L}$ of detergent mix (i.e., $36.8 \mathrm{~g} \mathrm{~L}^{-1} \mathrm{Na}_{2}$ EDTA $\times 2 \mathrm{H}_{2} \mathrm{O}, 22.3 \mathrm{~g} \mathrm{~L}^{-1} \mathrm{Na}-$ pyrophosphate $\times 10 \mathrm{H}_{2} \mathrm{O}$ and $5 \mathrm{~mL}$ TWEEN 80), $50 \mu \mathrm{L}$ of methanol and $350 \mu \mathrm{L}$ of ultrapure $\mathrm{H}_{2} \mathrm{O}$. This mixture was vortexed for $30 \mathrm{~min}$ and sonicated $4 \times 1 \mathrm{~s}$ at $10 \%$ amplitude, using a Sonopuls HD 3200 ultrasonic homogenizer equipped with a microtip probe (Bandelin Electronic, Berlin, Germany). Fifty microliters of this solution were mixed with $5 \mu \mathrm{L}$ of $1 \%$ hydrogen fluoride (HF) to dissolve fine mineral particles (Morono et al., 2009). After 10 minutes, the solution was filtered onto black $0.2 \mu \mathrm{m}$ polycarbonate track-etched membrane filters ( $\varnothing 25 \mathrm{~mm}$ Cyclopore, Whatman International Ltd, Maidstone, UK). Cells were stained with SYBR Green I (Molecular Probes Inc., Eugene, OR, USA), mounted and counted by epifluorescence microscopy (Leica DM2000 microscope, $100 \times$ magnification) with a blue filter set (Leica Filter Cube F1/RH, excitation filter $\lambda=490 / 15$ to $560 / 25 \mathrm{~nm}$, suppression filter at $\lambda=525 / 20$ to $605 / 30 \mathrm{~nm}$ ) and non-fluorescent immersion oil (Leica type $\mathrm{F}$ oil, $\mathrm{n}_{\mathrm{e}}{ }^{23}=1.518$, $\left.\mathrm{v}_{\mathrm{e}}=46\right)$.

\section{Intracellular and Extracellular DNA Extraction and Quantification}

The procedure of Alawi et al. (2014) was applied to extract eDNA and iDNA separately from single sediment samples. All extractions were performed in duplicates along with a negative control. In brief, we mixed $1.0 \mathrm{~g}$ of fresh sediment with $0.2 \mathrm{~g}$ of acid washed polyvinylpolypyrrolidone (PVPP) and $2.5 \mathrm{~mL}$ of $0.1 \mathrm{M}$ sodium phosphate buffer (Na-P-buffer). The sample slurry was centrifuged and the supernatant decanted off twice for a final volume of $7.5 \mathrm{~mL}$. The supernatant was centrifuged for $45 \mathrm{~min}$ at $4700 \times g$ to separate the iDNA (i.e., cell pellet, also containing viral particles) from the eDNA (i.e., supernatant). To avoid any DNA adsorption onto the rubber, we used $10 \mathrm{~mL}$ syringes without rubber and filtered the supernatant through $0.2 \mu \mathrm{m}$ cellulose acetate syringe filters (Sartorius, Göttingen, Germany) to remove any residual PVPP. The filtrate was mixed with three times its volume of $6 \mathrm{M}$ guanidine hydrochloride. Sixty microliters of silica particles were added to adsorb eDNA (Boom et al., 1990). After centrifugation, the supernatant was discarded and the eDNAcontaining silica pellet rinsed in $150 \mu \mathrm{L}$ of absolute ethanol and Tris-EDTA in equal amounts and centrifuged twice for complete drying. To desorb the eDNA, $150 \mu \mathrm{L}$ of Tris-EDTA buffer $(1 \mathrm{mM})$ were added to the silica pellet, vortexed and centrifuged. The final eDNA-containing supernatant was decanted off and stored. The desorption step was repeated to reach a final volume of $300 \mu \mathrm{L}$ of eDNA extract.

The iDNA extraction was performed using the Mobio PowerSoil DNA extraction and isolation kit. The content of the PowerBead Tube with $60 \mu \mathrm{L}$ of solution $\mathrm{C} 1$ and $500 \mu \mathrm{L}$ of NaP-buffer were added to a $15 \mathrm{~mL}$ centrifuge tube containing the cell pellet. The mixture was vortexed, sonicated for $6 \mathrm{~min}$, heated twice for $5 \mathrm{~min}$ at $70^{\circ} \mathrm{C}$ to lyse cells and centrifuged for $15 \mathrm{~min}$ at $4700 \times g$. The supernatant was processed in the same as the eDNA fraction adding $50 \mu \mathrm{L}$ of silica particles. Final iDNA elution volume was $100 \mu \mathrm{L}$.

DNA concentrations of all samples were measured using a Qubit 2.0 fluorometer (Invitrogen, Carlsbad, CA, USA) with 
$10 \mu \mathrm{L}$ of DNA template, $1 \mu \mathrm{L}$ of reagent and $190 \mu \mathrm{L}$ of buffer solution. The Qubit fluorescent dye targets DNA specifically, as compared to UV absorbance techniques which measure any compound absorbing at $260 \mathrm{~nm}$ (i.e., DNA, RNA, protein, free nucleotide, and excess salt). Measurements were performed in duplicates and the results are given as the average, error bars are one standard deviation.

\section{Polymerase Chain Reaction}

DNA extracts were purified following the Mobio PowerSoil experienced user protocol (www.mobio.com) and eluted in $100 \mu \mathrm{L}$ for eDNA and $65 \mu \mathrm{L}$ for iDNA. Purified DNA extracts were diluted 20 and 10 times for eDNA and iDNA, respectively, and used as templates in polymerase chain reaction (PCR) amplifications. PCR was performed with $2.5 \mu \mathrm{L}$ of DNA template, $12.5 \mu \mathrm{L}$ of MangoMix (Bioline, Life Science Company, London, $\mathrm{UK}), 0.5 \mu \mathrm{mol} \mathrm{L} \mathrm{L}^{-1}$ of each of the primers, $1 \mu \mathrm{L}$ of $\mathrm{MgCl}_{2}$ $(25 \mathrm{mM})$ and $8 \mu \mathrm{L}$ of Ultra-pure 18.2 M $\Omega$ PCR Water (Bioline). Negative controls were added to all PCR sets with $2.5 \mu \mathrm{L}$ of molecular grade water as template. Amplifications of the bacterial small subunit (16S) rRNA gene were performed using the bacterial universal primer pair GC-Uni331F (5'-CGC CCG CCG CGC GCG GCG GGC GGG GCG GGG GCA CGG GGG GTC CTA CGG GAG GCA GCA GT-3') and Eub797R (5'-GGA CTA CCA GGG TAT CTA ATC CTG TT-3'; Brands et al., 2009). PCR cycles were run as follows: 30 cycles of $95^{\circ} \mathrm{C}$ for $1 \mathrm{~min}, 57^{\circ} \mathrm{C}$ for $1 \mathrm{~min}$, and $72^{\circ} \mathrm{C}$ for $1 \mathrm{~min}$, with a final extension step of $10 \mathrm{~min}$ at $72^{\circ} \mathrm{C}$. Amplifications of the archaeal $16 \mathrm{~S}$ rRNA gene were performed using the archaeal universal primer pair GCUA751F (5'-CGC CCG CCG CGC GCG GCG GGC GGG GCG GGG GCA CGG GGG GCC GAC GGT GAG RGR YGA A-3') and UA1204R (5'-TTM GGG GCA TRC IKA CCT-3'; Baker and Cowan, 2004). PCR cycles were run as follows: 35 cycles of $95^{\circ} \mathrm{C}$ for $1.5 \mathrm{~min}, 60^{\circ} \mathrm{C}$ for $1.5 \mathrm{~min}$, and $72^{\circ} \mathrm{C}$ for $1.5 \mathrm{~min}$, with a final extension step of $10 \mathrm{~min}$ at $72^{\circ} \mathrm{C}$. For denaturing gradient gel electrophoresis (DGGE), $120 \mu \mathrm{L}$ archaeal PCR product were concentrated to $25 \mu \mathrm{L}$ using the Hi Yield PCR Clean-up and Gel-Extraction Kit (SLG Südlabor, München, Germany).

\section{Denaturing Gradient Gel Electrophoresis Analysis}

Eight percent polyacrylamide gels were prepared with a linear gradient from 35 to $60 \%$ of the denaturants urea and formamide. The $100 \%$ gradient solution was prepared using $1 \mathrm{~mL}$ of TAE $(50 \times), 21 \mathrm{~g}$ urea, $20 \mathrm{~mL}$ of formamide, $10 \mathrm{~mL}$ of $40 \%$ acrylamide/bis-acrylamide, and molecular grade water for a final volume of $50 \mathrm{~mL}$. The $0 \%$ gradient solution was prepared without urea or formamide. Gels were prepared with $17.5 \mathrm{~mL}$ of each solution, plus $50 \mu \mathrm{L}$ ammonium persulfate solution (APS) and $50 \mu \mathrm{L}$ tetramethylethylenediamine (TEMED) for polymerization. Twenty microliters of PCR product and $20 \mu \mathrm{L}$ of blue stain were loaded for each sample. Ten microliters of standard (i.e., 13 previously selected bands) with $10 \mu \mathrm{L}$ of blue stain were loaded in the center and on each side of the gels to reference band positions. Electrophoresis was run at $100 \mathrm{~V}$ for $16 \mathrm{~h}$ in $1 \times$ TAE buffer at $60^{\circ} \mathrm{C}$. Gels were stained for $30 \mathrm{~min}$ in $2.5 \mu \mathrm{L}$ of SYBR Gold nucleic acid gel stain (10,000 time concentrates, Invitrogen) diluted in $25 \mathrm{~mL} 1 \times$ TAE buffer. Gels were photographed under UV light. The Strati-Signal software (Vuillemin et al., 2011; Ndiaye et al., 2012) was then used to analyze DGGE gel pictures. Band numbers, intensity values and pattern lengths were extracted (Supplementary Material) to calculate Shannon indices. The Shannon index is calculated as follows: Shannon $=-\Sigma$ $(n i / N) \times \log (n i / N)$, where $n i$ is the height of each peak and $N$ the sum of all peak heights extracted from red green blue (RGB) intensity curves of each sample (Boon et al., 2001; Fromin et al., 2002).

\section{Band Sequencing and Phylogenetic Analysis}

In total, 131 bands were excised from DGGE gels under UV light. Gel bands were eluted in $20 \mu \mathrm{L}$ M $\Omega$ PCR Water (Bioline) and used as templates in PCR mixtures as described above without GC-clamp on the forward primers. PCR cycles were run as follows: three cycles of $95^{\circ} \mathrm{C}$ for $1 \mathrm{~min}, 57^{\circ} \mathrm{C}$ for $1 \mathrm{~min}$, and $72^{\circ} \mathrm{C}$ for $1 \mathrm{~min}$ followed by 27 cycles of $95^{\circ} \mathrm{C}$ for $30 \mathrm{~s}, 57^{\circ} \mathrm{C}$ for $30 \mathrm{~s}$, and $72^{\circ} \mathrm{C}$ for $30 \mathrm{~s}$ with a final extension step of $10 \mathrm{~min}$ at $72^{\circ} \mathrm{C}$ for Bacteria, and 35 cycles of $95^{\circ} \mathrm{C}$ for $50 \mathrm{~s}, 58^{\circ} \mathrm{C}$ for $50 \mathrm{~s}$, and $72^{\circ} \mathrm{C}$ for $50 \mathrm{~s}$ with a final extension step of $10 \mathrm{~min}$ at $72^{\circ} \mathrm{C}$ for Archaea. PCR products were run on $1 \%$ agarose gels and targeted DNA bands excised under UV light to remove residual dimers. DNA bands were purified using the Hi Yield PCR Gel-Extraction Kit (SLG Südlabor) with final elution in $25 \mu \mathrm{L}$ of Ultra-pure 18.2 $\mathrm{M} \Omega$ PCR Water (Bioline). DNA concentrations were checked on a NanoPhotometer P330 (Implen, München, Germany) and DNA extracts sent to GATC Biotech AG (European Custom Sequencing Centre, Köln, Germany) for Sanger sequencing using primers Eub797R and UA751F. Sequences were aligned on Sequencher v. 5.1 (Gene Codes Corporation, Ann Arbor, MI, USA) and primers selectively cut off. Chimeras were detected using the online program Bellerophon (Huber et al., 2004). All DGGE sequences have been deposited in the GenBank database under accession numbers KR091588 to KR091718.

The SINA online v.1.2.11 (Pruesse et al., 2007, 2012) was used to align, search and classify our sequences. Closest match sequences were downloaded from the SILVA database as taxonomic references, uploaded on the ARB platform and plotted into phylogenetic trees using the maximum-likelihood method with the RAxML algorithm with advanced bootstrap refinement from 100 replicates (Ludwig et al., 2004). DGGE fragment sequences were added to the RAxML tree using the bacteria positional variability by parsimony algorithm. Two separate phylogenetic trees were plotted for Bacteria and Archaea with iDNA and eDNA sequences together (Supplementary Material). Sequences from representative taxa were then selected to build one single tree based on 15 eDNA and 15 iDNA fragments (Figure 4).

\section{RESULTS}

\section{Water Column}

CTD water column profiles (Figure 2) obtained at each site provided evidence for weak thermal stratification occurring around $25 \mathrm{~m}$ water depth with a corresponding drop of $1.5^{\circ} \mathrm{C}$. Below this depth, water column temperatures did not vary 
significantly, with less than $1^{\circ} \mathrm{C}$ decrease in the subsequent $175 \mathrm{~m}$. Oxygen profiles indicated that the water column is fully oxic $(250 \mu \mathrm{M})$ down to $60 \mathrm{~m}$ depth where oxygen concentration declines gradually over the following $70 \mathrm{~m}$, the deepest part of the water column is anoxic. Thus, the water-sediment interface could be considered oxic at the shallow site (i.e., $60 \mathrm{~m}$ depth) and anoxic at the intermediate (i.e., $153 \mathrm{~m}$ depth) and deep sites (i.e., $200 \mathrm{~m}$ depth). Chlorophyll $a$ fluorescence profiles showed that phytoplankton biomass is highest at $50 \mathrm{~m}$ water depth. Transmission profiles revealed negative peaks around 50 and $130 \mathrm{~m}$ depth indicating higher concentrations of suspended particles in these depth intervals.

\section{Pore Water Geochemistry}

Sodium $\left(\mathrm{Na}^{+}\right)$, calcium $\left(\mathrm{Ca}^{2+}\right)$, and magnesium $\left(\mathrm{Mg}^{2+}\right)$ were the only cations we were able to detect in the pore water by IC, only $\mathrm{Ca}^{2+}$ and $\mathrm{Mg}^{2+}$ were quantified. $\mathrm{Ca}^{2+}$ and $\mathrm{Mg}^{2+}$ profiles (Figure 3A) did not show much variability with depth, concentrations were around $25 \mu \mathrm{M}$ and $130 \mu \mathrm{M}$ for $\mathrm{Ca}^{2+}$ and $\mathrm{Mg}^{2+}$, respectively. The intermediate site displays one single significant peak at about $20 \mathrm{~cm}$ depth. At the deep site, $\mathrm{Mg}^{2+}$ values tend to increase slightly with depth to values around $150 \mu \mathrm{M} . \mathrm{NH}_{4}{ }^{+}$concentrations in the uppermost pore water sample were similar at all three sites (ca. $22 \mu \mathrm{M}$ ) and showed a general increase with depth, the gradient became increasingly steeper from the shallow to the deep site (Figure 3A), leading to concentrations of 40,60 , and $130 \mu \mathrm{M}$ at the bottom ends of the cores, respectively. Similarly, dissolved $\mathrm{Fe}^{2+}$ concentrations increased from the shallow to the deep site and with sediment depth, with values ranging from 0,5 , and $35 \mu \mathrm{M}$ in surface sediment to 10,20 , and $50 \mu \mathrm{M}$ at the bottom of the core, respectively. The $\mathrm{Fe}^{2+}$ profile of the deep site exhibits a slight excursion to lower values in the upper $10 \mathrm{~cm}$ of sediment, below this depth values increase constantly like at the other sites.

Chloride $\left(\mathrm{Cl}^{-}\right)$and sulfate $\left(\mathrm{SO}_{4}{ }^{2-}\right)$ were the main inorganic anions in the pore water. Nitrate, nitrite, and phosphate were below detection limit. Profiles for $\mathrm{Cl}^{-}$(Figure 3A) displayed constant concentrations around 40 to $20 \mu \mathrm{M}$ with little difference between sites although with a general decrease with increasing water depth. Some minor peaks up to $60 \mu \mathrm{M}$ could be observed in the upper $15 \mathrm{~cm}$ at all sites. $\mathrm{SO}_{4}{ }^{2-}$ concentrations were mainly in the single $\mu \mathrm{M}$ range and often close to the quantification $(5 \mu \mathrm{M})$ and detection $(2 \mu \mathrm{M})$ limits. At the shallow site, concentrations were generally higher, with values about $20 \mu \mathrm{M}$ in the uppermost $4 \mathrm{~cm}$, but decreasing gradually to values between 2 and $5 \mu \mathrm{M}$ at the base of the core. At the intermediate site, sulfate was detectable at all depths but the measurements were close to or below the quantification limit, except for two peaks of 40 and $15 \mu \mathrm{M}$ at 0.5 and $22.5 \mathrm{~cm}$ depth, respectively. At the deep site, all $\mathrm{SO}_{4}{ }^{2-}$ concentrations were around the detection limit.

Respective ion concentrations measured directly above the water-sediment interface in cores from the shallow, intermediate, and deep site are given in Table 1.

\section{Potential Sulfate Reduction Rates}

Potential rates of sulfate reduction and their depth distribution (Figure 3A) differed significantly between sites. At the shallow site, we found maximum rates of ca. $7 \mathrm{nmol} \mathrm{cm} \mathrm{cm}^{-3}$ day $^{-1}$ within the upper $10 \mathrm{~cm}$ of sediment. Below this depth, SRR

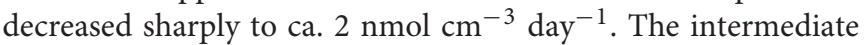
site displayed two peaks of elevated SRR of ca. 11 and $8 \mathrm{nmol} \mathrm{cm}{ }^{-3}$ day $^{-1}$ at 2 and $22 \mathrm{~cm}$ depth which corresponds to anomalous peaks in sulfate concentrations; at all other depths, rates were minimal $<2 \mathrm{nmol} \mathrm{cm}^{-3}$ day $^{-1}$. At the deep site, rates were generally lower than at the other sites (1 to maximum $3 \mathrm{nmol} \mathrm{cm}{ }^{-3} \mathrm{day}^{-1}$ ). Altogether, the measurements demonstrated that viable sulfate-reducing bacteria (SRB) were present at all three sites, but were more active at the shallow site. The results also showed a general decrease in SRR with increasing water depth due to decreasing bottom water $\mathrm{SO}_{4}{ }^{2-}$ concentrations and hence lower diffusive fluxes of sulfate into the sediment. Because $\mathrm{SO}_{4}{ }^{2-}$ concentrations were in many cases barely detectable $(>2 \mu \mathrm{M})$ and well below the lower limit of quantification $(5 \mu \mathrm{M})$, the absolute values of the potential SRR have to be carefully considered. We also acknowledge that our measured rates may differ from those on-site due to some biologically unavailable background $\mathrm{SO}_{4}{ }^{2-}$ (Roden and Tuttle, 1993; Roden and Wetzel, 1996). However, the data clearly show that the sulfate pool is turned over within days, implying strong internal recycling. In the absence of available $\mathrm{SO}_{4}{ }^{2-}$ in the pore water, the necessity to turn to reduced sulfur compounds also implies that $\mathrm{SO}_{4}{ }^{2-}$ reduction processes are slowed down.

\section{Organic Matter}

TOC values (Figure 3B) increased from the shallow to the deep site. The shallow site had TOC contents around $2 \%$ in the upper few centimeters with a subsequent increase by about $1 \%$ and constant values over the rest of the core. The intermediate site exhibited oscillating values between 4.5 and $3.5 \%$ in the uppermost $10 \mathrm{~cm}$, continuing with lower and more constant values of ca. 3-3.5\% down to the base of the record. At the deep site, TOC concentrations decreased gradually from $4.5 \%$ in the uppermost section to $3 \%$ at the base of the core. In parallel to these results, TC peaks around $5 \mathrm{~cm}$ depth at both the intermediate and deep site indicated the likely presence of authigenic carbonates (Figure 3B).

The $\mathrm{C}_{\text {org }} / \mathrm{N}$ ratio profiles resembled those of TOC, with values generally increasing from the shallow site to the deep site. Overall, values increased gradually from 8.5 to 12.5 at the shallow site and varied in between 10.5 and 12.5 at the intermediate site. At the deep site, the ratios ranged from 10.5 to 15.5 in the uppermost samples and gradually decrease to 11.5 in the lower part. Altogether, TOC and $\mathrm{C}_{\mathrm{org}} / \mathrm{N}$ ratio profiles appear to reflect the different bottom water oxygenation conditions at the three sites as values generally increase with water depth.

\section{Total Cell Counts}

Total cell counts (Figure 3B) were much higher at the shallow site than at the other sites. At all three sites, numbers declined steeply in the upper $5 \mathrm{~cm}$, followed by a more gradual decrease over the remainder of the core. Compared to the other two sites, cell concentrations at the shallow site were up to 31 times higher in the $0-1 \mathrm{~cm}$ depth interval (i.e., $\log _{10}=9.6,8.4$, and 8.1 ) and still 
A

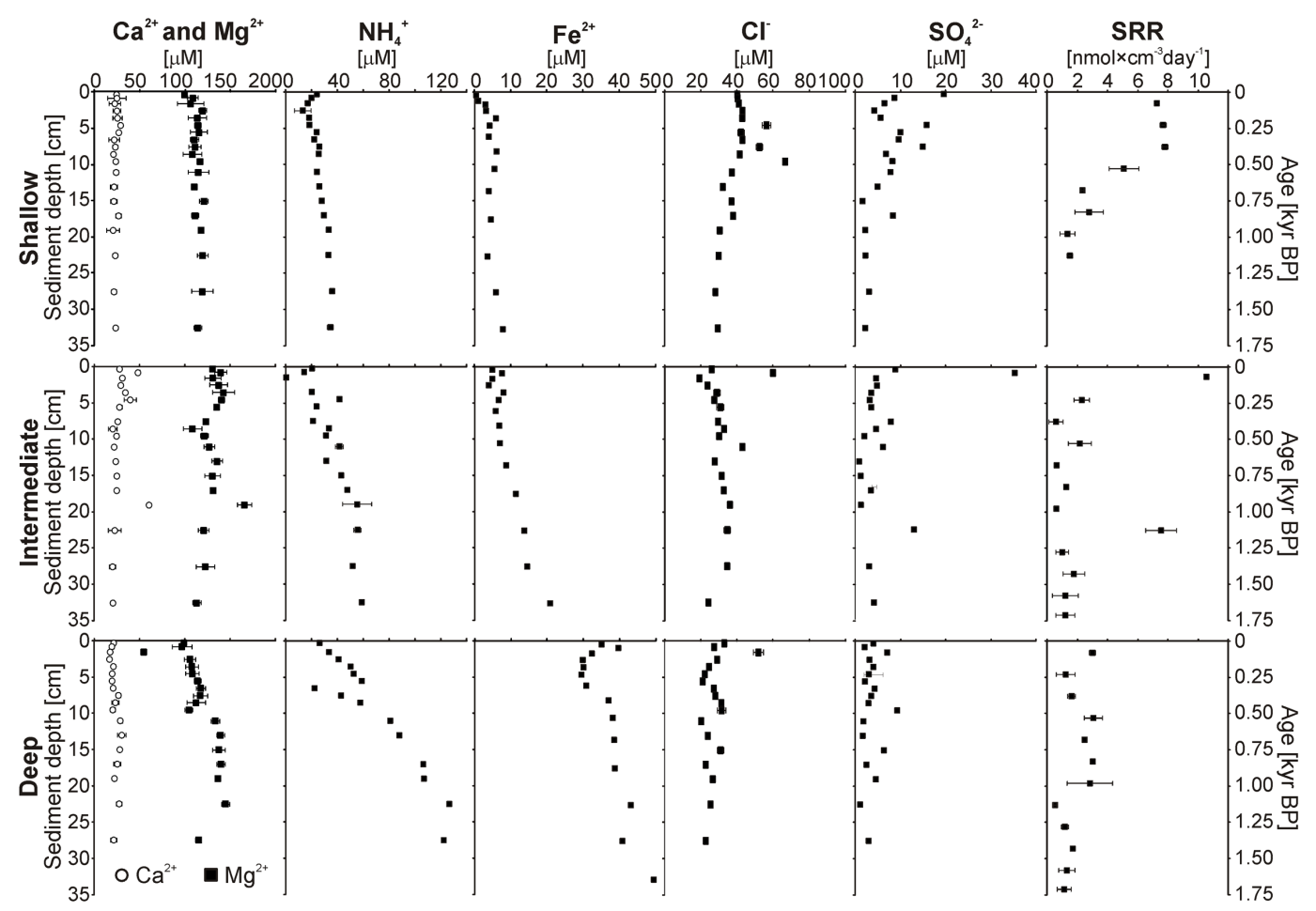

B

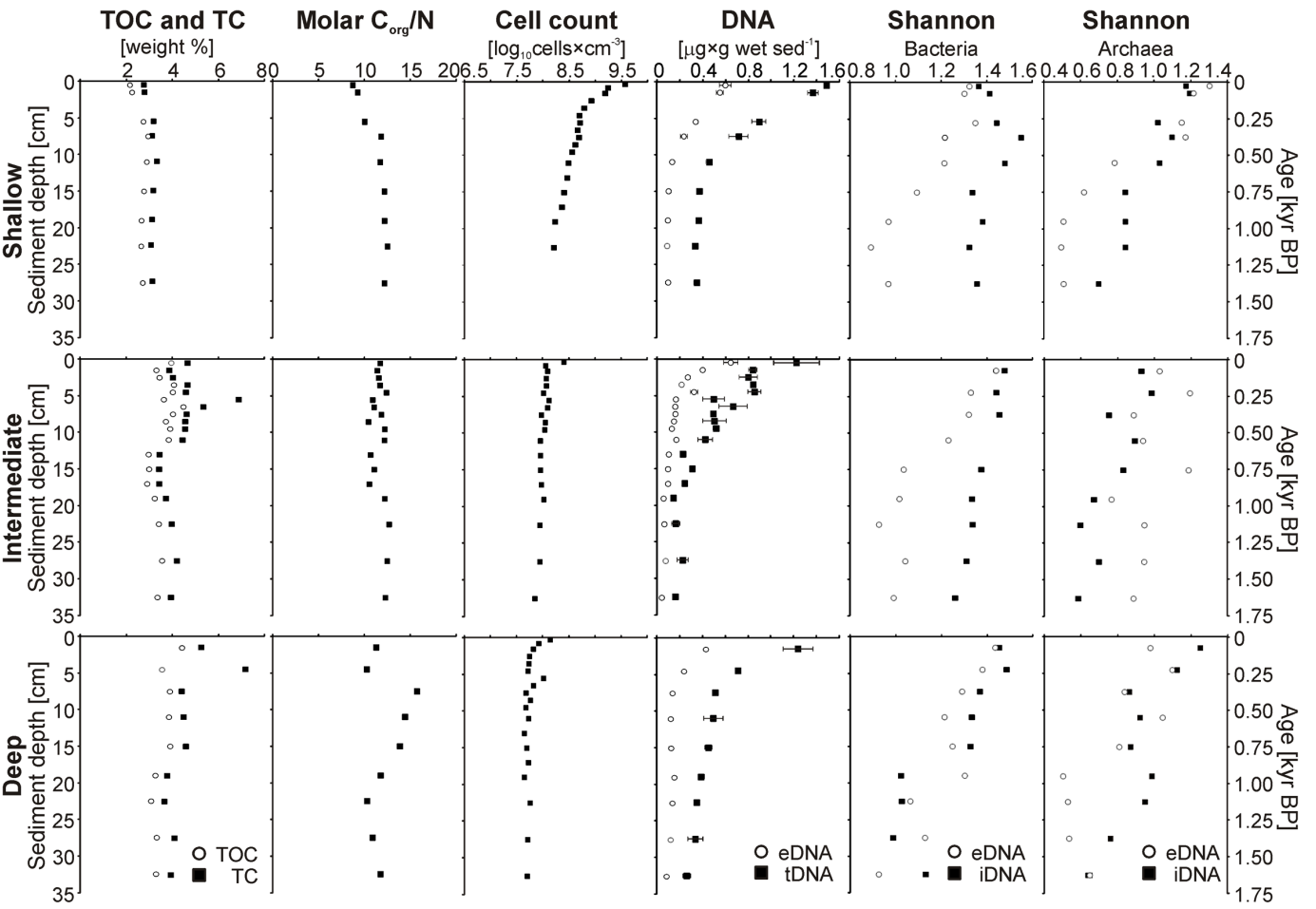

FIGURE 3 | Multiple profiles established on short sediment cores. For consistency, results for the three different sites are displayed vertically according to their water depths. (A) From left to right: Total organic carbon and total carbon (wt\%); molar $\mathrm{C}_{\mathrm{org}} / \mathrm{N}$ ratio measured in bulk sediments; calcium, magnesium, chloride, and sulfate concentrations $(\mu \mathrm{M})$ measured in the pore water; potential sulfate reduction rates $\left(\mathrm{nmol} \times \mathrm{cm}^{-3}\right.$ day $^{-1}$ ) obtained after $24 \mathrm{~h}$ incubation experiments; ammonium concentrations $(\mu \mathrm{M})$ in the pore water measured by cell dialysis. (B) From left to right: Cell counts in log scale (log 10 cells $\left.\times \mathrm{cm}^{-3}\right)$; concentrations of extracellular DNA (gray dots) and total DNA (black squares) $\left(\mu \mathrm{g} \times \mathrm{g}_{\text {wet sediment }}{ }^{-1}\right.$ ), with distance between the two curves corresponding to intracellular DNA concentrations; Shannon index established from bacterial and archaeal DGGE gel features, with eDNA (gray dots) and iDNA (black squares) displayed separately; range-weighted richness index for bacterial DNA (square) and archaeal DNA (dots), with eDNA (gray) and iDNA (black) displayed separately. 
TABLE 1 | Bottom water geochemistry of Lake Towuti.

\begin{tabular}{|c|c|c|c|c|c|c|}
\hline \multirow[b]{2}{*}{ Site } & \multicolumn{5}{|c|}{ Geochemistry of bottom waters ( $\mu \mathrm{M})$} & \multirow[b]{2}{*}{$\mathrm{NH}_{4}^{+}$} \\
\hline & Depth (m) & $\mathrm{Ca}^{2+}$ & $\mathbf{M g}^{2+}$ & $\mathrm{Cl}^{-}$ & $\mathrm{SO}_{4}{ }^{2-}$ & \\
\hline Shallow & 60 & $28.6 \pm 6.1$ & $145.4 \pm 8.9$ & $37.3 \pm 0.9$ & $20.2 \pm 0.7$ & $<6$ \\
\hline Intermediate & 153 & $25.3 \pm 0.1$ & $134.8 \pm 7.0$ & $38.4 \pm 1.9$ & $11.9 \pm 0.4$ & $20.3 \pm 0.8$ \\
\hline Deep & 200 & $23.8 \pm 2.6$ & $148.7 \pm 4.3$ & $20.5 \pm 0.5$ & $11.8 \pm 0.2$ & $13.8 \pm 0.2$ \\
\hline
\end{tabular}

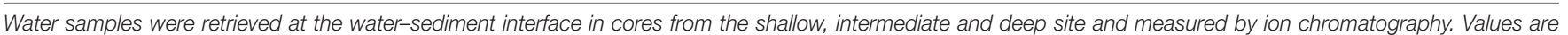
displayed in [ $\mu \mathrm{M}$ ] followed by one standard deviation.

up to three times higher at the base of the cores (i.e., $\log _{10}=8.2$, 7.8, and 7.7). The profiles from the intermediate and deep site were very similar, although values were generally lower at the deep site.

\section{Intracellular and Extracellular DNA Concentrations}

Concentrations of eDNA (Figure 3B) were very similar at all three sites, with concentrations around $0.6 \mu \mathrm{g} \mathrm{g}^{-1}$ in the uppermost layer, decreasing to ca. $0.2 \mu \mathrm{g} \mathrm{g}^{-1}$ at $10 \mathrm{~cm}$ depth and a final decline to minimum values $\left(<0.1 \mu \mathrm{g} \mathrm{g}^{-1}\right)$ at the bottom of the core. Total DNA ( $\mathrm{tDNA}=\mathrm{eDNA}+\mathrm{iDNA}$ ) concentration profiles mimic those of eDNA, with concentrations of 1.6, 1.2, $1.2 \mu \mathrm{g} \mathrm{g}^{-1}$ in the surface layer and $0.4,0.2$, and $0.3 \mu \mathrm{g} \mathrm{g}^{-1}$ in the bottom layer for the shallow, intermediate, and deep site, respectively. Results showed that concentrations of eDNA and iDNA display similar trends and that iDNA was the dominant fraction in total DNA.

In order to assess the recovery rate of cells and respective amount of extracted iDNA with this procedure, iDNA concentrations were divided by the corresponding cell densities of each sample and results reported in femtogram (fg) of DNA per cell. Averaged values per site were 1.0, 3.7, and $6.5 \mathrm{fg}$ DNA cell ${ }^{-1}$ at the shallow, intermediate and deep site, respectively (data not shown). Published values range from 1.6 to 8.9 fg DNA cell ${ }^{-1}$ (Bakken and Olsen, 1989; Button and Robertson, 2001). In nearby Lake Matano, phosphorus limitation resulted in reduced RNA concentrations per cell (Yao et al., 2016). Similarly in Lake Towuti, the variable sorption capacity of the sediment could influence $\mathrm{P}$ availability and DNA concentration per cell. Concerning the presence of viral DNA (Torti et al., 2015), protein capsids are not quantified as DNA with a Qubit 2.0 fluorometer. Moreover, sediment particles also strongly adsorb virions and multiple studies of freshwater sediments showed a low impact of viruses on bacterial mortality (Filippini and Middelboe, 2007 and references therein). We acknowledge that viral DNA should be found in our extracts, albeit as a minor fraction as we did not use a specifically adapted extraction protocol necessary to lyse the capsids (Danovaro and Middelboe, 2010).

\section{Bacterial and Archaeal Fingerprinting}

DGGE provided an assessment of the relative preservation of eDNA at the three sites along with a first fingerprinting of bacterial and archaeal diversity associated with both eDNA and iDNA fractions. In general, eDNA gel features faded with increasing sample depth and led to the transformation of clear bands into smears and further disappearance (Supplementary Material). At all three sites, Shannon indices of bacterial eDNA (Figure 3B) decreased almost linearly with depth, whereas those of bacterial iDNA display different trends at each site. Values increased within the upper part of the core before gradually decreasing at the shallow site, decreased linearly at the intermediate site and sharply dropped in the lower half of the core at the deep site. Values of archaeal eDNA (Figure 3B) rapidly declined in the upper $20 \mathrm{~cm}$ and stayed minimal below that depth at the shallow site, showed high scatter and little decrease at the intermediate site and dropped at ca. $20 \mathrm{~cm}$ followed by constant values at the deep site. Shannon values of archaeal iDNA were similar for each site, with fluctuations in upper sediments and gradual decrease in lower sediments, although the intermediate site generally displayed lower values. Richness indices (Supplementary Material) clearly demonstrated the predominance of Bacteria over Archaea.

\section{Phylogeny of Sequenced DGGE Fragments}

Sequences of eDNA were mainly representative of aerobic and anaerobic heterotrophs, with taxa identified as Actinobacteria, Nitrospirae, Chloroflexi, and Thermoplasmatales (Supplementary Material). Taking into account the local conditions of the sediment, these sequences were likely related to microorganisms evolving in the water column and preserved as eDNA in the sediment. However, Actinobacteria are known ubiquists in soils, aquatic habitats and sediments and could also reflect a terrestrial origin arising from eroded soils transported to the lake. We considered eDNA sequences clustering among iDNA-related taxa to derive from cell lysis in the sediment (e.g., Betaproteobacteria, Deltaproteobacteria, Firmicutes). Additionally, planktonic species in the bottom waters could become benthic at the water-sediment interface before being buried and could, thus, also be preserved as iDNA.

Taxa identified from iDNA fragments were mostly related to Beta- and Deltaproteobacteria, Firmicutes, and Methanomicrobiales (Figure 4 and Supplementary Material). Sequences of Betaproteobacteria plotted among Rhodocyclaceae with closest cultivated taxa represented by Thiobacillus and Denitratisoma. Sequences of Deltaproteobacteria were closest to Desulfovibrio, Desulfuromonas, Deferrisoma, Geobacter, and 


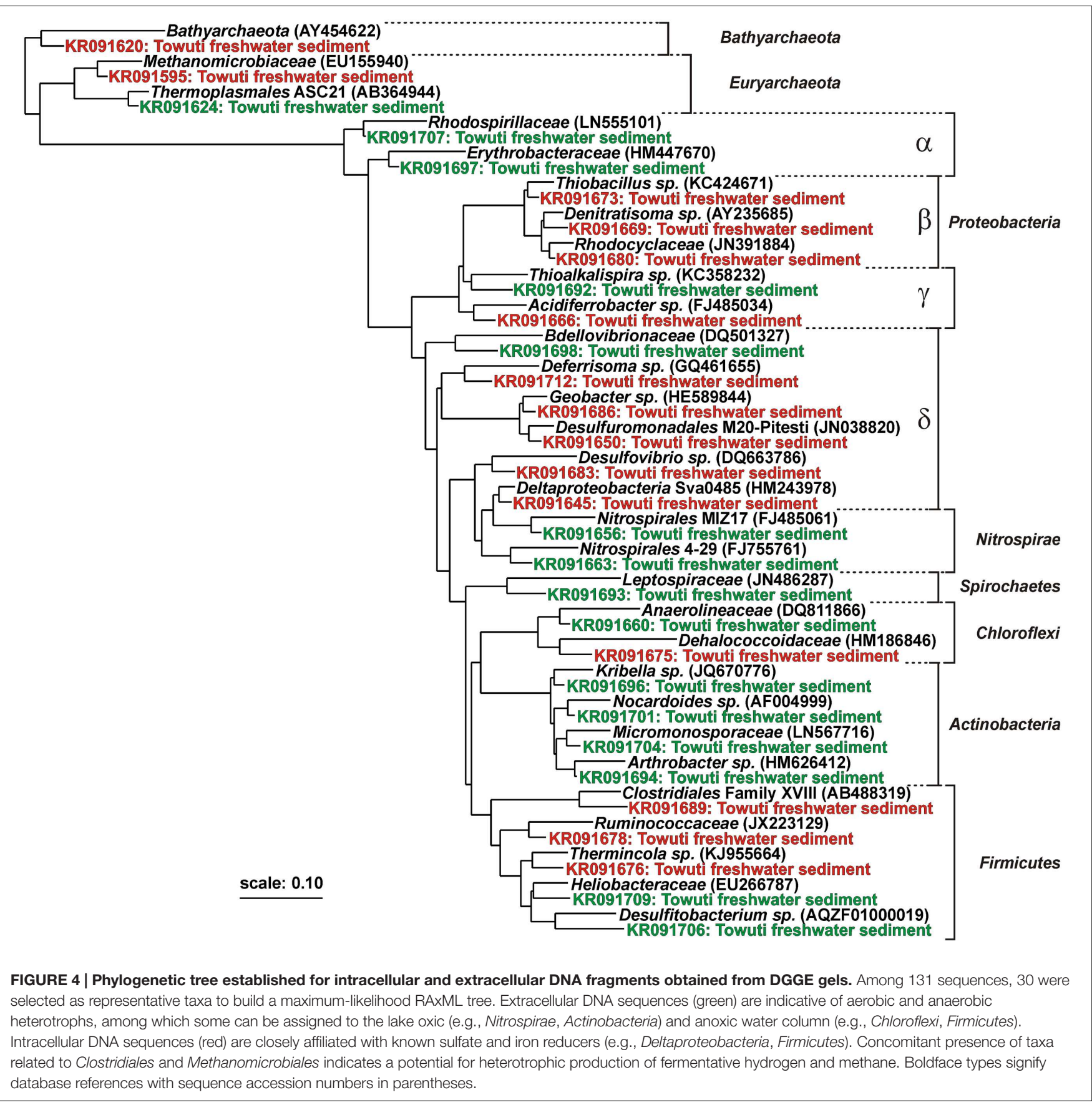

candidate order Sva0485. Together with the potential SRR, these sequences provided evidence for the presence of sedimentary SRB along with microorganisms capable of dissimilatory sulfur and ferric iron reduction at all three sites. Sequences of Firmicutes related to Thermincola supported the presence of iron-reducing bacteria. Finally, taxa among Ruminococcaceae and Clostridiales were representative of heterotrophic anaerobes, whose concomitance with Methanomicrobiales indicated that fermentative hydrogen can be produced via ferredoxin reduction and used during methanogenesis (Hallenbeck, 2009).

\section{DISCUSSION}

\section{Water Column Conditions and Organic Matter Sedimentation}

Varying oxygenation levels in the water column, especially at the water-sediment interface are expected to lead to differences in production, degradation, and burial of OM in sediments at the three sites (Katsev and Crowe, 2015 and references therein). Chlorophyll a concentrations are highest around $50 \mathrm{~m}$ water depth, while transmission profiles indicate suspended matter 
close to the oxycline at $130 \mathrm{~m}$ water depth (Figure 2), pointing toward a redox interface similar to the one observed in the water column of nearby Lake Matano, although less steep (Crowe et al., 2008a). At the intermediate site, a long-term shift in the oxycline was recorded during the mid-Holocene in the form of elevated ferric iron and siderite (i.e., $\mathrm{FeCO}_{3}$ ) concentrations (Costa et al., 2015). Due to the low sedimentation rates (i.e., $2 \mathrm{~mm} \mathrm{year}^{-1}$; Vogel et al., 2015), redox fluctuations would be hard to detect at our sampling resolution.

TOC contents indicate increased OM burial from the shallow to the deep site (Figure 3A), associated with a shift toward more recalcitrant $\mathrm{OM}$ composition (i.e., higher $\mathrm{C}_{\mathrm{org}} / \mathrm{N}$ ratio). Although degradation processes in an anoxic water column are generally slower (Katsev and Crowe, 2015), iron reduction below the oxycline can foster desorption of labile OM and microbial uptake of nitrogen and phosphorus (Zegeye et al., 2012), thereby increasing carbon burial linked to bacterial production. Remineralization of organic compounds leads to the production of $\mathrm{NH}_{4}{ }^{+}$, which can be oxidized or accumulate, depending on the presence of suitable reactants in the water column. $\mathrm{NH}_{4}{ }^{+}$concentrations in bottom waters (Table 1 ) indicate that degradation of sinking particulate $\mathrm{OM}$ is indeed continuous in the water column, leading to the accumulation of less reactive organic material at the deep site (Amon and Benner, 1996). This interpretation is also consistent with the diverse taxa identified from our eDNA sequences, which corresponded to both aerobic and anaerobic heterotrophs, namely Actinobacteria, Nitrospirae, Chloroflexi, and Thermoplasmatales, and secondarily Alpha- and Gammaproteobacteria (Figure 4; and Supplementary Material). However, final discrimination of eDNA sources cannot be achieved. For example, Actinobacteria could originate from soils eroded from the catchment, transported to the lake and preserved within refractory OM. Although we did not detect any photoautotrophs, certain elements can still be assigned to planktonic assemblages coming from the epilimnion (e.g., Nitrospirales) and hypolimnion (e.g., Anaerolineales). Our interpretation is that labile OM from primary producers is rapidly degraded by heterotrophic species that are active in the water column, resulting in the preferential preservation of heterotrophic over phototrophic sequences in the eDNA (Vuillemin et al., 2016). This is also consistent with the transmission decrease at the oxycline (i.e., $130 \mathrm{~m}$ ), which we interpret as iron reduction leading to desorption of phosphorus compounds and thereby promoting anaerobic heterotrophic processes. Data from Lake Matano show that dissolution of particulate $\mathrm{Fe}^{3+}$ occurs at and below the pycnocline along with the liberation of phosphorus and concomitant production of methane and ammonia (Crowe et al., 2008b; Katsev et al., 2010).

\section{Pore Water Geochemistry}

High $\mathrm{Ca}^{2+}$ and $\mathrm{Mg}^{2+}$ concentrations in pore waters (Figure 3A) likely reflect continued weathering of mafic/ultramafic minerals derived from the catchment of the Malili Lake system (Kadarusman et al., 2004). Although fairly constant, variations in these profiles could possibly imply precipitation and/or dissolution of authigenic carbonates (i.e., $\mathrm{Ca}-\mathrm{Mg}-\mathrm{FeCO}_{3}$ ) within the sediment. At the intermediate and deep site, the presence of authigenic carbonates can be inferred from peaks in TC profiles. The diagenetic sequence known for freshwater sediments in relation to pore water geochemistry (i.e., $\mathrm{Ca}-\mathrm{Mg}$ siderite, calcite, ankerite, dolomite) suggests the formation of early diagenetic siderite (Berner, 1980; Matsumoto and Iijima, 1981), which is consistent with the decline in dissolved $\mathrm{Fe}^{2+}$ concentrations at the deep site. Lake Matano and Lake Towuti are both ironrich but also extremely low-sulfate environments, far lower than most aquatic environments studied to date (Crowe et al., 2014). Moreover, microbial reduction processes in the water column likely take place at or directly below the oxycline, as shown for $\mathrm{SO}_{4}{ }^{2-}$ concentrations in Lake Matano, which decrease drastically along with a rapid increase of dissolved $\mathrm{Fe}^{2+}$ (Crowe et al., 2008a). In Lake Towuti, $\mathrm{SO}_{4}{ }^{2-}$ concentrations measured at the water/sediment interface decreased from the shallow to the deep site (Table 1), supporting our assumption that sulfate reduction already takes place in the anoxic bottom water of the intermediate and deep site. As a result pore water $\mathrm{SO}_{4}{ }^{2-}$ concentrations in the uppermost sediment samples decreased toward the deep site and were rapidly depleted with sediment depth at all sites. Pore water $\mathrm{Fe}^{2+}$ concentrations show the opposite trend, increasing from the shallow to the deep site and with core depth, showing an increasingly steeper gradient between sites with maximum values around $45 \mu \mathrm{M}$ (Figure 3A). The production, consumption, and dynamics of $\mathrm{NH}_{4}{ }^{+}$in bottom waters seemed to differ between the three sites as indicated by their respective concentrations (i.e., $<6,20$, and $13 \mu \mathrm{M}$ ) and the very similar $\mathrm{NH}_{4}{ }^{+}$concentrations in the uppermost sediment sample at all three sites (ca. $25 \mu \mathrm{M}$ ). The $\mathrm{NH}_{4}{ }^{+}$profile of the deep site is indeed the only one that clearly indicates $\mathrm{NH}_{4}{ }^{+}$diffusion out of the sediment into the bottom waters. Whereas nitrification could take place in the oxic bottom waters of the shallow site, the potential accumulation of $\mathrm{NH}_{4}{ }^{+}$in the anoxic bottom waters of the two other sites remains unclear.

\section{Sediment Microorganisms and Extracellular DNA Remineralization}

Several studies showed that bacterial abundance and diversity in lake sediments correlate with environmental parameters such as salinity, pH, OM content, and sediment depth (Nam et al., 2008; Zeng et al., 2009; Borsodi et al., 2012), and can also reflect climatic variations due to forcing of conditions during sediment deposition (Dong et al., 2010; Vuillemin et al., 2013, 2014). Lake Towuti's surface sediments are characterized by comparatively high cell densities that decrease from the shallow to the deep site. At all sites, cell counts decrease by one order of magnitude over the uppermost $5 \mathrm{~cm}$ below the water-sediment interface and remain more or less constant over the rest of the core (Figure 3B). The corresponding iDNA concentrations follow a similar trend, whereas Shannon indices show more variability between the three sites. Potential SRR measurements with radiotracer (Figure 3A) further demonstrate that $\mathrm{SRB}$ are present and viable at all sites, but are more active at the shallow site, showing some correspondence to Shannon indices. We interpret these data as the positive response of bacterial populations to geochemical conditions corresponding with higher bottom water $\mathrm{SO}_{4}{ }^{2-}$ 
concentrations and increased burial of labile $\mathrm{OM}$ and reactive ferric iron into the sediment.

With regard to recording of past lake conditions by eDNA, water temperatures of Lake Towuti are approximately $28^{\circ} \mathrm{C}$ throughout the year, which is rather unfavorable for eDNA preservation (Lindahl, 1993; Renshaw et al., 2015). Although sorption capacities in the sediment were expected to vary between the three sampling sites, eDNA distribution patterns are similar, displaying a rapid decrease in the uppermost $5 \mathrm{~cm}$ followed by constant but low concentrations over the rest of the cores (Figure 3B). The decline of eDNA Shannon indices also indicates a gradual loss of genetic information associated with the degradation and shortening of eDNA sequences over time (Corinaldesi et al., 2008). Such decrease as a function of sediment depth can be attributed to a combination of sediment sorption capacity, microbial uptake, and degradation as well as rates of cell lysis. We argue that the observed lower eDNA concentrations result from an overall decrease in metabolic activity and cell lysis rate, along with the immediate degradation of the free eDNA fraction resulting in diminishing Shannon values. In the longterm, eDNA preservation would greatly depend on metabolic turnover rates and its potential stabilization by ferric mineral phases (Glasauer et al., 2003; Pinchuk et al., 2008). In this context, preliminary results indicate that reactive ferric iron persists down to $15 \mathrm{~m}$ sediment depth at concentrations up to nearly $2 \mathrm{wt} \%$ (Simister et al., 2016).

\section{Phylogeny of Intracellular DNA and Presumed Metabolic Processes}

Microbial fingerprinting (Figure 4; and Supplementary Material) revealed the presence of microorganisms related to taxa commonly known for iron and sulfate reduction as well as methanogenesis, indicating that the autochthonous microbial communities have the metabolic capacity for these processes. Among Proteobacteria, certain taxa were affiliated with Denitratisoma (Fahrbach et al., 2006), Thiobacillus (Schedel and Trüper, 1980; Haaijer et al., 2006), and Acidiferrobacter (Hallberg et al., 2011), indicating putative capacity for both lithotrophic and organotrophic processes driven through use of reduced sulfur and iron as electron donors. However, these Beta- and Gammaproteobacteria typically exhibit metabolic versatility with the capacity to shift between different modes of facultative metabolisms (Masters and Madigan, 1983; Hiraishi and Hoshino, 1984; Ferguson et al., 1987), making it impossible to assess metabolism from taxonomic information alone. This could also indicate that these taxa are planktonic in the bottom waters, then benthic at the water-sediment interface until burial.

Interestingly, sequences of Deltaproteobacteria at the shallow and intermediate site included taxa assigned to the candidate order Sva0485 and Desulfovibrio, which are often reported as part of SRB consortia (Kleindienst et al., 2014; Bar-Or et al., 2015). These sequences were correspondingly identified in sediments with the highest measured SRR. In addition, detection of Desulfuromonas M20-Pitesti, Deferrisoma and Geobacterrelated sequences may indicate that the metabolic capacity to reduce sulfur and iron is evenly distributed across all three sites (Slobodkina et al., 2012; Greene, 2014). DGGE fragments affiliated with Thermincola also point at a metabolic potential for iron reduction (Zavarzina et al., 2007). In addition, taxa related to Ruminococcaceae and Clostridiales were representative of heterotrophic anaerobes that can produce fermentative hydrogen via ferredoxin (i.e., $\mathrm{Fe}_{2} \mathrm{~S}_{2}$ protein cluster) reduction (Hallenbeck, 2009). Their concomitance with Methanomicrobiales suggests that $\mathrm{H}_{2} / \mathrm{CO}_{2}$ reduction is a likely pathway for methane production (Thauer et al., 2008; Kaster et al., 2009), although formate and alcohols could also be used (Ohren, 2014).

Together, our measurements of potential sulfate reduction and our findings of microbial taxa commonly involved in microbial sulfate and iron reduction suggest that ferruginous sediments support microorganisms that degrade OM via sulfate reduction, in spite of the extremely low sulfate concentrations, in collaboration with diverse iron-reducing bacteria, fermenters, and methanogens. Seemingly, such complementary metabolisms imply desorption of OM following iron reduction and its remineralization to methane. The low pore water $\mathrm{SO}_{4}{ }^{2-}$ concentrations (single $\mu \mathrm{M}$ ) and the relatively high potential SRR (single to tens of nmol $\mathrm{cm}^{-3} \mathrm{day}^{-1}$ ) also demonstrate that the sulfate pool is turned over within days. This suggests that reoxidation of reduced sulfur compounds occurs through a cryptic S-cycle driven by iron (Norði et al., 2013; Hansel et al., 2015) in order to maintain these high SRR. A likely mechanism for such recycling is the disproportionation of elemental sulfur linked to ferric iron reduction (Thamdrup et al., 1993; Holmkvist et al., 2011). Moreover, unless methanogens are being outcompeted by iron reducers (Roden and Wetzel, 1996), the persistence of ferric iron in deeper sediment could be seen as an indicator for processes involved in anaerobic oxidation of methane (Hallam et al., 2004).

\section{CONCLUSION}

Stratification of Lake Towuti's water column gave rise to different biogeochemical conditions in deeper parts of the water column and at the water-sediment interface at the three study sites. Respiration processes led to the gradual depletion of electron acceptors with increasing water depth, with microbial $\mathrm{Fe}^{3+}$ and $\mathrm{SO}_{4}{ }^{2-}$ reduction occurring below the oxycline. As a result of microbial uptake of nitrogen and phosphorus, carbon burial increased with water depth while $\mathrm{NH}_{4}{ }^{+}$accumulated in anoxic bottom waters. Sediments at the shallow site exhibited more labile $\mathrm{OM}$ as well as higher pore water $\mathrm{SO}_{4}{ }^{2-}$ concentrations and, consequently, harbored the highest cell densities and potential SRR. Retrieved eDNA sequences confirmed the role of microbial degradation within the water column, with some aerobic and anaerobic heterotrophic elements potentially linked to the epilimnion and hypolimnion. Nevertheless, eDNA was substantially degraded in the uppermost sediment layers at all three sites, leading to the gradual loss of genetic information. Fingerprinting of iDNA revealed taxa common in SRB consortia, along with known iron reducers and methanogens at all sites. Our results attest that Lake Towuti's sediments support microorganisms displaying complementary 
metabolic capabilities related to sulfur, iron and methane cycling. Relatively high SRR could be maintained in these ferruginous sediments through a cryptic sulfur cycle driven by iron reduction. The related loss of the sedimentary OM sorption capacity over time would then promote OM remineralization to methane. However, ferric iron phases may persist in deeper sediment layers, questioning the availability of organic substrates rather than that of reactive iron. To conclude whether they be related to climate or in-lake processes, redox changes in the water column appear to lead to variable burial of OM, electron acceptors and reactive metal species in the sediments. Regarding the entire lacustrine record, a long-term shift to more oxic conditions would lead to persistence of electron acceptors in deeper sediments and could promote metabolic activity by the subsurface biosphere.

\section{AUTHOR CONTRIBUTIONS}

AV performed DNA extractions, DGGE procedure, genetic and image analyses, designed the figures, and led the writing of the present manuscript. AF sampled during field campaign, performed geochemical analyses and cell counts. MA designed and supervised DNA extractions and genetic analyses. SAC sampled during field campaign and conducted the CTD cast measurements. $\mathrm{CH}$ and $\mathrm{SN}$ fulfilled the research permit procedure and sampled during field campaign. DW provided important financial and technical support and supervised genetic analyses. JK designed the study, sampled during field campaign, supervised geochemical analyses and cell counts. All authors have taken part in the manuscript revisions and agreed with its scientific content.

\section{REFERENCES}

Alawi, M., Schneider, B., and Kallmeyer, J. (2014). A procedure for separate recovery of extra- and intracellular DNA from a single marine sediment sample. J. Microbiol. Methods 104, 36-42. doi: 10.1016/j.mimet.2014.06.009

Aldrian, E., and Susanto, R. D. (2003). Identification of three dominant rainfall regions within Indonesia and their relationship to sea surface temperature. Int. J. Climatol. 23, 1435-1452. doi: 10.1002/joc.950

Amon, R. M. W., and Benner, R. (1996). Bacterial utilization of different size classes of dissolved organic matter. Limnol. Oceanogr. 41, 41-51. doi: 10.4319/lo.1996.41.1.0041

Baker, G., and Cowan, D. A. (2004). 16 S rDNA primers and the unbiased assessment of thermophile diversity. Biochem. Soc. Trans. 32, 218-221. doi: 10.1042/BST0320218

Bakken, L. R., and Olsen, R. A. (1989). DNA-content of soil bacteria of different cell size. Soil Biol. Biochem. 21, 789-793. doi: 10.1016/0038-0717(89)90172-7

Baldwin, D. S. (2013). Organic phosphorus in the aquatic environment. Environ. Chem. 10, 439-454. doi: 10.1079/9780851998220.0309

Bar-Or, I., Ben-Dov, E., Kushmaro, A., and Sivan, O. (2015). Methane-related changes in prokaryotes along geochemical profiles in sediments of Lake Kinneret (Israel). Biogeosciences 12, 2847-2860. doi: 10.5194/bg-12-2847-2015

Berner, R. A. (1980). Early Diagenesis: A Theoretical Approach. Princeton, NJ: Princeton University Press, 256.

Boom, R., Sol, C. J., Salimans, M. M., Jansen, C. L., Wertheim-van Dillen, P. M., and van der Noordaa, J. (1990). Rapid and simple method for purification of nucleic acids. J. Clin. Microbiol. 28, 495-503.

Boon, N., De Windt, W., Verstraete, W., and Top, E. M. (2001). Evaluation of nested-PCR-DGGE (denaturing gradient gel electrophoresis) with groupspecific 16 rRNA primers for the analysis of bacterial diversities from

\section{FUNDING}

This study was financially and logistically supported by the ICDP priority program of the Deutsche Forschungsgemeinschaft (DFG Schwerpunktprogramm) through grants to JK (KA 2293/8-1) and AV (VU 94/1-1); the Swiss National Science Foundation (SNSF Grant P2GEP2_148621 to AV); the Helmholtz Center Potsdam, German Research Center for Geoscience (GFZ), and an NSERC Discovery grant (0487) to SC.

\section{ACKNOWLEDGMENTS}

We thank Tri Widiyanto and his staff from the Indonesia Research Center for Limnology for their administrative support in obtaining the Scientific Research Permit. Jan Axel Kitte, Carriayne Jones, and Céline C. P. Michiels are thanked for their assistance during sampling at Lake Towuti, and PT Vale Indonesia for field support. Maria Schindler's help in the cell extraction procedure and Dyke Scheidemann's assistance in elemental analysis are kindly acknowledged.

\section{SUPPLEMENTARY MATERIAL}

The Supplementary Material for this article can be found online at: http://journal.frontiersin.org/article/10.3389/fmicb. 2016.01007

different wastewater treatment plants. FEMS Microbiol. Ecol. 39, 101-112. doi: 10.1111/j.1574-6941.2002.tb00911.x

Borsodi, A. K., Felföldi, T., Máthé, I., Bognár, V., Knáb, M., Krett, G., et al. (2012). Phylogenetic diversity of bacterial and archaeal communities inhabiting the saline Lake Red located in Sovata, Romania. Extremophiles 17, 87-98. doi: 10.1007/s00792-012-0496-2

Bramburger, A. J., Hamilton, P. B., Hehanussa, P. E., and Haffner, G. D. (2008). Processes regulating the community composition and relative abundance of taxa in the diatom communities of the Malili Lakes, Sulawesi Island, Indonesia. Hydrobiologia 615, 215-224. doi: 10.1007/s10750-0089562-2

Brands, B., Vianna, M. E., Seyfarth, I., Conrads, G., and Horz, H. P. (2009). Complementary retrieval of $16 \mathrm{~S}$ rRNA gene sequences using broad-range primers with inosine at the 3'-terminus: implications for the study of microbial diversity. FEMS Microbiol. Ecol. 71, 157-167. doi: 10.1111/j.15746941.2009.00786.x

Button, D. K., and Robertson, B. R. (2001). Determination of DNA content of aquatic bacteria by flow cytometry. Appl. Environ. Microbiol. 67, 1636-1645. doi: 10.1128/AEM.67.4.1636-1645.2001

Byers, S. C., Mills, E. L., and Stewart, P. L. (1978). A comparison of methods of determining organic carbon in marine sediments, with suggestions for a standard method. Hydrobiologia 58, 43-47. doi: 10.1007/BF00018894

Calvert, S. J., and Hall, R. (2007). Cenozoic evolution of the Lariang and Karama regions, North Makassar Basin, western Sulawesi, Indonesia. Petrol. Geosci. 13, 353-368. doi: 10.1144/1354-079306-757

Ceccherini, M. T., Ascher, J., Agnelli, A., Borgogni, F., Pantani, O. L., and Pietramellara, G. (2009). Experimental discrimination and molecular characterization of the extracellular soil DNA fraction. Antonie Van Leeuwenhoek 96, 653-657. doi: 10.1007/s10482-009-9354-3 
Cecchio, C., Ruggiero, P., Curci, M., Colombo, C., Palumbo, G., and Stotzky, G. (2005). Binding of DNA from Bacillus subtilis on montmorillonite-humic acidsaluminium or iron hydroxypolymers: effects on transformation and protection against DNase. Soil Sci. Soc. Am. J. 69, 834-841. doi: 10.2136/sssaj2004.0166

Cleaves, H. J., Crapster-Pregont, E., Jonsson, C. M., Jonsson, C. L., Sverjensky, D. A., and Hazen, R. A. (2011). The adsorption of short single-stranded DNA oligomers to mineral surfaces. Chemosphere 83, 1560-1567. doi: 10.1016/j.chemosphere.2011.01.023

Corinaldesi, C., Barucca, M., Luna, G. M., and Dell'Anno, A. (2011). Preservation, origin and genetic imprint of extracellular DNA in permanently anoxic deepsea sediments. Mol. Ecol. 20, 642-654. doi: 10.1111/j.1365-294X.2010.04958.x

Corinaldesi, C., Beolchini, F., and Dell'Anno, A. (2008). Damage and degradation rates of extracellular DNA in marine sediments: implications for the preservation of gene sequences. Mol. Ecol. 17, 3939-3951. doi: 10.1111/j.1365294X.2008.03880.x

Corinaldesi, C., Dell'Anno, A., and Danovaro, R. (2007). Early diagenesis and trophic role of extracellular DNA in different benthic ecosystems. Limnol. Oceanogr. 52, 1710-1717. doi: 10.4319/lo.2007.52.4.1710

Costa, K. M., Russell, J. M., Vogel, H., and Bijaksana, S. (2015). Hydrological connectivity and mixing of Lake Towuti, Indonesia, in response to paleoclimatic changes over the last 60,000 years. Palaeogeogr. Palaeoclimatol. Palaeoecol. 417, 467-475. doi: 10.1016/j.palaeo.2014.10.009

Crowe, S. A., Jones, C. A., Katsev, S., Magen, C., O’Neill, A., Sturm, A., et al. (2008a). Photoferrotrophs thrive in an Archean Ocean analogue. Proc. Natl. Acad. Sci. U.S.A. 105, 15938-15943. doi: 10.1073/pnas.0805313105

Crowe, S. A., Katsev, S., Hehanussa, P., Haffner, G. D., Sundby, B., Mucci, A., et al. (2008b). The biogeochemistry of tropical lakes: a case study from Lake Matano, Indonesia. Limnol. Oceanogr. 53, 319-331. doi: 10.4319/lo.2008.53. 1.0319

Crowe, S. A., Katsev, S., Leslie, K., Sturm, A., Magen, C., Nomosatryo, S., et al. (2011). The methane cycle in ferruginous Lake Matano. Geobiology 9, 61-78. doi: 10.1111/j.1472-4669.2010.00257.x

Crowe, S. A., Pannalal, S. J., Fowle, D. A., Cioppa, M. T., Symons, D. T. A., Haffner, G. D., et al. (2004). Biogeochemical cycling in Fe-rich sediments from Lake Matano, Indonesia. Int. Symp. Water Rock Interact. 11, 1185-1189.

Crowe, S. A., Paris, G., Katsev, S., Jones, C. A., Kim, S. T., Zerkle, A. L., et al. (2014). Sulfate was a trace constituent of Archaean seawater. Science 346, 735-739. doi: 10.1126/science. 1258966

Crowe, S. A., Roberts, J. A., Weisener, C. G., and Fowle, D. A. (2007). Alteration of iron-rich lacustrine sediments by dissimilatory iron-reducing bacteria. Geobiology 5, 63-73. doi: 10.1111/j.1472-4669.2006.00086.x

Danovaro, R., and Middelboe, M. (2010). "Separation of free virus particles from sediments in aquatic systems," in Manual of Aquatic Viral Ecology, eds S. W. Wilhelm, M. G. Weinbauer, and C. A. Suttle (Waco, TX: American Society of Limnology and Oceanography, Inc.), 74-81.

Dell'Anno, A., and Corinaldesi, C. (2004). Degradation and turnover of extracellular DNA in marine sediments: ecological and methodological considerations. Appl. Environ. Microbiol. 70, 4384-4386. doi: 10.1128/AEM.70.7.4384-4386.2004

Dong, H., Jiang, H., Yu, B., Liu, X., and Zhang, C. (2010). Impacts of environmental change and human activity on microbial ecosystems on the Tibetan Plateau, NW China. GSA Today 20, 4-10. doi: 10.1130/GSATG75A.1

Dong, H., Kukkadapu, R. K., Fredrickson, J. K., Zachara, J. M., Kennedy, D. W., and Kostandarithes, H. M. (2003). Microbial reduction of structural Fe(III) in illite and goethite. Environ. Sci. Technol. 37, 1268-1276. doi: 10.1021/es020919d

Fahrbach, M., Kuever, J., Meinke, R., Kämpfer, P., and Hollender, J. (2006). Denitratisoma oestradiolicum gen. nov., sp. nov., a 17ß-oestradiol-degrading, denitrifying betaproteobacterium. Int. J. Syst. Evol. Microbiol. 56, 1547-1552. doi: 10.1099/ijs.0.63672-0

Ferguson, S. J., Jackson, B., and McEwan, A. G. (1987). Anaerobic respiration in the Rhodospirillaceae: characterisation of pathways and evaluation of roles in redox balancing during photosynthesis. FEMS Microbiol. Rev. 46, 117-143. doi: 10.1111/j.1574-6968.1987.tb02455.x

Filippini, M., and Middelboe, M. (2007). Viral abundance and genome size distribution in the sediment and water column of marine and freshwater ecosystems. FEMS Microbiol. Ecol. 60, 397-410. doi: 10.1111/j.15746941.2007.00298.x
Freudenthal, T., Wagner, T., Wenzhöfer, F., Zabel, M., and Wefer, G. (2001). Early diagenesis of organic matter from sediments of the eastern subtropical Atlantic: evidence from stable nitrogen and carbon isotopes. Geochim. Cosmochim. Acta 65, 1795-1808. doi: 10.1016/S0016-7037(01)00554-3

Fromin, N., Hamelin, J., Tarnawski, S., Roesti, D., Jourdain-Miserez, K., Forestier, N., et al. (2002). Statistical analysis of denaturing gel electrophoresis (DGE) fingerprinting patterns. Environ. Microbiol. 4, 634-643. doi: 10.1046/j.1462-2920.2002.00358.x

Glasauer, S., Weidler, P. G., Langley, S., and Beveridge, T. J. (2003). Controls of Fe reduction and mineral formation by a subsurface bacterium. Geochim. Cosmochim. Acta 67, 1277-1288. doi: 10.1016/S0016-7037(02)01199-7

Golightly, J. P. (2010). "Progress in understanding the evolution of nickel laterites," in The Challenge of Finding New Mineral Resources - Global Metallogeny, Innovative Exploration, and New Discoveries, eds R. J. Goldfarb, E. E. Marsh, and T. Monecke (Littleton, CO: Society of Economic Geologists Special Publication 15), 451-485.

Greene, A. C. (2014). "The family desulfuromonadaceae," in The Prokaryotes, eds E. Rosenberg, E. F. DeLong, S. Lory, E. Stackebrandt, and F. Thompson (Heidelberg: Springer Berlin), 143-155. doi: 10.1007/978-3-642-39044-9_380

Haaijer, S. C. M., Van der Welle, M. E. W., Schmid, M. C., Lamers, L. P. M., Jetten, M. S. M., and Op den Camp, H. J. M. (2006). Evidence for the involvement of betaproteobacterial Thiobacilli in the nitrate-dependent oxidation of iron sulfide minerals. FEMS Microbiol. Ecol. 58, 439-448. doi: 10.1111/j.15746941.2006.00178.x

Haffner, G. D., Hehanussa, P. E., and Hartoto, D. (2001). "The biology and physical processes of large lakes of Indonesia: Lakes Matano and Towuti," in The Great Lakes of the World (GLOW): Food-Web, Health, and Integrity, eds M. Munawar and R. E. Hecky (Leiden: Blackhuys), 183-194.

Hall, P. O. J., and Aller, R. C. (1992). Rapid small-volume, flow injection analysis for ¿CO2 and NH4+ in marine and freshwaters. Limnol. Oceanogr. 37, 1113-1119. doi: 10.4319/lo.1992.37.5.1113

Hallam, S. J., Putnam, N., Preston, C. M., Detter, J. C., Rokhsar, D., Richardson, P. M., et al. (2004). Reverse methanogenesis: testing the hypothesis with environmental genomics. Science 305, 1457-1462. doi: 10.1126/science.1100025

Hallberg, K. B., Hedrich, S., and Johnson, D. B. (2011). Acidiferrobacter thiooxydans, gen. nov. sp. nov.; an acidophilic, thermo-tolerant, facultatively anaerobic iron- and sulfur-oxidizer of the family Ectothiorhodospiraceae. Extremophiles 15, 271-279. doi: 10.1007/s00792-011-0359-2

Hallenbeck, P. C. (2009). Fermentative hydrogen production: principles, progress and prognosis. Int. J. Hydrogen Energy 34, 7379-7389. doi: 10.1016/j.ijhydene.2008.12.080

Hansel, C. M., Lentini, C. J., Tang, Y., Johnston, D. T., Wankel, S. D., and Jardine, P. M. (2015). Dominance of sulfur-fueled iron oxide reduction in low-sulfate freshwater sediments. ISME J. 9, 2400-2412. doi: 10.1038/ismej.2015.50

He, J., Zhang, L., Jin, S., Zhu, Y., and Liu, F. (2008). Bacterial communities inside and surrounding soil iron-manganese nodules. Geomicrobiol. J. 25, 14-24. doi: 10.1080/01490450701829014

Herder, F., Nolte, A. W., Pfaender, J., Schwarzer, J., Hadiaty, R. K., and Schliewen, U. K. (2006). Adaptive radiation and hybridization in Wallace's Dreamponds: evidence from sailfin silversides in the Malili Lakes of Sulawesi. Proc. Biol. Sci. 7, 2209-2217. doi: 10.1098/rspb.2006.3558

Hiraishi, A., and Hoshino, Y. (1984). Distribution of rhodoquinone in Rhodospirillaceae and its taxonomic implications. J. Gen. Appl. Microbiol. 30, 435-448. doi: 10.2323/jgam.30.435

Holmkvist, L., Ferdelman, T. G., and Jørgensen, B. B. (2011). A cryptic sulfur cycle driven by iron in the methane zone of marine sediment (Aarhus Bay, Denmark). Geochim. Cosmochim. Acta 75, 3581-3599. doi: 10.1016/j.gca.2011.03.033

Horsfield, B., and Kieft, T. L. (2007). "The GeoBiosphere," in Continental Scientific Drilling: A Decade of Progress, and Challenges for the Future, eds U. Harms, C. Koeberl, and M. D. Zoback (Heidelberg: Springer), 163-212. doi: 10.1007/9783-540-68778-8

Huber, T., Faulkner, G., and Hugenholtz, P. (2004). Bellerophon: a program to detect chimeric sequences in multiple sequence alignments. Bioinformatics 20, 2317-2319. doi: 10.1093/Bioinformatics/Bth226

Jones, C. A., Crowe, S. A., Sturm, A., Leslie, K. L., MacLean, L. C. W., Katsev, S., et al. (2011). Biogeochemistry of manganese in ferruginous Lake Matano, Indonesia. Biogeosciences 8, 2977-2991. doi: 10.5194/bg-8-2977-2011 
Jørgensen, B. B. (1978). A comparison of methods for the quantification of bacterial sulfate reduction in coastal marine sediments. I. Measurements with radiotracer techniques. Geomicrobiol. J. 1, 11-27. doi: 10.1080/01490457809377721

Kadarusman, A., Miyashita, S., Maruyama, S., Parkinson, C. D., and Ishikawa, A. (2004). Petrology, geochemistry and paleogeographic reconstruction of the East Sulawesi Ophiolite, Indonesia. Tectonophysics 392, 55-83. doi: 10.1016/j.tecto.2004.04.008

Kallmeyer, J., Ferdelman, T. G., Weber, A., Fossing, H., and Jørgensen, B. B. (2004). A cold chromium distillation procedure for radiolabeled sulfide applied to sulfate reduction measurements. Limnol. Oceanogr. Methods 2, 171-180. doi: 10.4319/lom.2004.2.171

Kallmeyer, J., Pockalny, R., Adhikari, R. R., Smith, D. C., and D'Hondt, S. (2012). Global distribution of microbial abundance and biomass in subseafloor sediment. Proc. Natl. Acad. Sci. U.S.A. 109, 16213-16216. doi: 10.1073/pnas.1203849109

Kallmeyer, J., Smith, D. C., Spivack, A. J., and D’Hondt, S. (2008). New cell extraction procedure applied to deep subsurface sediments. Limnol. Oceanogr. Methods 6, 236-245. doi: 10.4319/lom.2004.2.171

Kaster, A.-K., Moll, J., Parey, K., and Thauer, R. K. (2009). Coupling of ferredoxin and heterodisulfide reduction via electron bifurcation in hydrogenotrophic methanogenic archaea. Proc. Natl. Acad. Sci. U.S.A. 108, 2981-2986. doi: 10.1073/pnas.101676110

Katsev, S., and Crowe, S. A. (2015). Organic carbon burial efficiencies in sediments: the power law of carbon mineralization revisited. Geology 43, 607-610. doi: $10.1130 / \mathrm{G} 36626.1$

Katsev, S., Crowe, S. A., Mucci, A., Sundby, B., Nomosatryo, S., Haffner, G. D., et al. (2010). Mixing and its effects on biogeochemistry in the persistently stratified, deep, tropical Lake Matano, Indonesia. Limnol. Oceanogr. 55, 763-776. doi: 10.4319/lo.2010.55.2.0763

Kleindienst, S., Herbst, F.-A., Stagars, M., von Netzer, F., von Bergen, M., Seifert, J., et al. (2014). Diverse sulfate-reducing bacteria of the Desulfosarcina/Desulfococcus clade are the key alkane degraders at marine seeps. ISME J. 8, 2029-2044. doi: 10.1038/ismej.2014.51

Leeuw, T., Boss, E. S., and Wright, D. L. (2013). In situ measurements of phytoplankton fluorescence using low cost electronics. Sensors 13, 7872-7883. doi: $10.3390 /$ s 130607872

Lehmusluoto, P., Machbub, B., Terangna, N., Rusmiputro, S., Achmad, F., Boer, L., et al. (1995). National Inventory of the Major Lakes and Reservoirs in Indonesia. Helsingfors: Edita Publishing Oy.

Lindahl, T. (1993). Instability and decay of the primary structure of DNA. Nature 362, 709-715. doi: 10.1038/362709a0

Ludwig, W., Strunk, O., Westram, R., Richter, L., Meier, H., Yadhukumar, et al. (2004). ARB: a software environment for sequence data. Nucleic Acids Res. 32, 1363-1371. doi: 10.1093/nar/gkh293

Masters, R. A., and Madigan, M. (1983). Nitrogen metabolism in the phototrophic bacteria Rhodocyclus purpureus and Rhodospirillum tenue. J. Bacteriol. 155, 222-227.

Matsumoto, R., and Iijima, A. (1981). Origin and diagenetic evolution of Ca$\mathrm{Mg}-\mathrm{Fe}$ carbonates in some coalfields of Japan. Sedimentology 28, 239-259. doi: 10.1111/j.1365-3091.1981.tb01678.x

Morono, Y., Terada, T., Masui, N., and Inagaki, F. (2009). Discriminative detection and enumeration of microbial life in marine subsurface sediments. ISME J. 3, 503-511. doi: 10.1038/ismej.2009.1

Nam, Y. D., Sung, Y., Chang, H. W., Roh, S. W., Kim, K. H., Rhee, S. K., et al. (2008). Characterization of the depth-related changes in the microbial communities in Lake Hovsgol sediment by 16 S rRNA gene-based approaches. J. Microbiol. 46, 125-136. doi: 10.1007/s12275-007-0189-1

Ndiaye, M., Davaud, E., Ariztegui, D., and Fall, M. (2012). A semi automated method for laminated sediments analysis. Int. J. Earth Sci. 3, 206-210. doi: 10.4236/ijg.2012.31023

Norði, K. A., Thamdrup, B., and Schubert, C. J. (2013). Anaerobic oxidation of methane in an iron-rich Danish freshwater lake sediment. Limnol. Oceanogr. 58, 546-554. doi: 10.4319/lo.2013.58.2.0546

Ohren, A. (2014). “The family methanomicrobiaceae," in The Prokaryotes, eds E. Rosenberg, E. F. DeLong, S. Lory, E. Stackebrandt, and F. Thompson (Heidelberg: Springer), 231-246. doi: 10.1007/978-3-642-38954-2

Pietramellara, G., Ascher, J., Borgogni, F., Ceccherini, M. T., Guerri, G., and Nannipieri, P. (2008). Extracellular DNA in soil and sediment: fate and ecological relevance. Biol. Fertil. Soils 45, 219-235. doi: 10.1007/s00374-0080345-8

Pinchuk, G. E., Ammons, C., Culley, D. E., Li, S.-M. W., McLean, J. S., Romine, M. F., et al. (2008). Utilization of DNA as a sole source of phosphorus, carbon, and energy by Shewanella spp.: ecological and physiological implications for dissimilatroy metal reduction. Appl. Environ. Microbiol. 74, 1198-1208. doi: 10.1128/AEM.02026-07

Pruesse, E., Peplies, J., and Glöckner, F. O. (2012). SINA: accurate high-throughput multiple sequence alignment of ribosomal RNA genes. Bioinformatics 28, 1823 1829. doi: 10.1093/bioinformatics/bts 252

Pruesse, E., Quast, C., Knittel, K., Fuchs, B. M., Ludwig, W., Peplies, J., et al. (2007). SILVA: a comprehensive online resource for quality checked and aligned ribosomal RNA sequence data compatible with ARB. Nucleic Acids Res. 35, 7188-7196. doi: 10.1093/nar/gkm864

Renshaw, M. A., Olds, B. P., Jerde, C. J., McVeigh, M. M., and Lodge, D. M. (2015). The room temperature preservation of filtered environmental DNA samples and assimilation into a phenol-chloroform-isoamyl acohol DNA extraction. Mol. Ecol. Resour. 15, 168-176. doi: 10.1111/1755-0998.12281

Roden, E. E., and Tuttle, J. H. (1993). Inorganic sulfur turnover in oligohaline estuarine sediments. Biogeochemistry 22, 81-105. doi: 10.1007/BF00002706

Roden, E. E., and Wetzel, R. G. (1996). Organic carbon oxidation and suppression of methane production by microbial Fe(III) oxide reduction in vegetated and unvegetated freshwater wetland sediments. Limnol. Oceanogr. 41, 1733-1748. doi: 10.4319/lo.1996.41.8.1733

Russell, J. M., and Bijaksana, S. (2012). The Towuti drilling project: paleoenvironments, biological evolution, and geomicrobiology of a tropical Pacific lake. Sci. Dril. 14, 68-71. doi: 10.2204/iodp.sd.14.11.2012

Russell, J. M., Vogel, H., Konecky, B. L., Bijaksana, S., Huang, Y., Melles, M., et al. (2014). Glacial forcing of central Indonesian hydroclimate since 60,000 y B.P. Proc. Natl. Acad. Sci. U.S.A. 111, 5100-5105. doi: 10.1073/pnas.1402373111

Schedel, M., and Trüper, H. G. (1980). Anaerobic oxidation of thiosulfate and elemental sulfur in Thiobacillus denitrificans. Arch. Microbiol. 124, 205-210. doi: $10.1007 / \mathrm{BF} 00427728$

Schibler, J., Moore, D., and De Borba, B. (2007). Setting Meaningful Detection and Quantitation Limits for Chromatography Methods. Sunnyvale, CA: PITTCON 2007 Presentation, Dionex Corporation.

Simister, R., Bauer, K., Vuillemin, A., Fowle, D., Russell, J., Kallmeyer, J., et al. (2016). Biogeochemistry of Ferruginous Sediments from Lake Towuti, Indonesia. Abstract No. Gold2016: Abs: 4994. Available at: http://goldschmidt.info/2016/ab stracts/abstractView?abstractId $=4994$

Slobodkina, G. B., Reysenbach, A.-L., Panteleeva, A. N., Kostrikina, N. A., Wagner, I. D., Bonch-Osmolovskaya, E. A., et al. (2012). Deferrisoma camini gen. nov., sp. nov., a moderately thermophilic, dissimilatory iron(III)-reducing bacterium from a deep-sea hydrothermal vent that forms a distinct phylogenetic branch in the Deltaproteobacteria. Int. J. Syst. Evol. Microbiol. 62, 2463-2468. doi: 10.1099/ijs.0.038372-0

Tamuntuan, G., Bijaksana, S., King, J., Russell, J., Fauzi, U., Maryunani, K., et al. (2015). Variation of magnetic properties in sediments from Lake Towuti, Indoensia, and its paleoclimatic significance. Palaeogeogr. Palaeoclimatol. Palaeoecol. 420, 163-172. doi: 10.1016/j.palaeo.2014.12.008

Thamdrup, B., Finster, K., Hansen, J. W., and Bak, F. (1993). Bacterial disproportionation of elemental sulfur coupled to chemical reduction of iron and manganese. Appl. Environ. Microbiol. 59, 101-108.

Thauer, R. K., Kaster, A.-K., Seedorf, H., Buckel, W., and Hedderich, R. (2008). Methanogenic archaea: ecologically relevant differences in energy conservation. Nat. Rev. Microbiol. 6, 579-591. doi: 10.1038/nrmicro1931

Torti, A., Lever, M. A., and Jørgensen, B. B. (2015). Origin, dynamics and implications of extracellular DNA pools in marine sediments. Mar. Genomics 24, 185-196. doi: 10.1016/j.margen.2015.08.007

Viollier, E., Inglett, P. W., Hunter, K., Roychoudhury, A. N., and Van Cappellen, P. (2000). The ferrozine method revisited: $\mathrm{Fe}(\mathrm{II}) / \mathrm{Fe}(\mathrm{III})$ determination in natural waters. Appl. Geochem. 15, 785-790. doi: 10.1016/S0883-2927(99)00097-9

Vogel, H., Russell, J. M., Cahyarini, S. Y., Bijaksana, S., Wattrus, N., Rethemeyer, J., et al. (2015). Depositional modes and lake-level variability at Lake Towuti, Indonesia, during the past $\sim 29$ kyr BP. J. Paleolimnol. 54, 359-377. doi: 10.1007/s10933-015-9857-z

Vuillemin, A., Ariztegui, D., Leavitt, P. R., Bunting, L., and The Pasado Science Team (2016). Recording of climate and diagenesis through sedimentary DNA 
and fossil pigments at Laguna Potrok Aike, Argentina. Biogeosciences 13, 2475-2492. doi: 10.5194/bg-13-2475-2016

Vuillemin, A., Ariztegui, D., Lücke, A., Mayr, C., and The Pasado Science Team (2014). Paleoenvironmental conditions define current sustainability of microbial populations in Laguna Potrok Aike sediments, Argentina. Aquat. Sci. 76, 101-114. doi: 10.1007/s00027-013-0317-4

Vuillemin, A., Ariztegui, D., and the Pasado Science Team (2013). Geomicrobiological investigations in subsaline maar lake over the last 1500 years. Quat. Sci. Rev. 71, 119-130. doi: 10.1016/j.quascirev.2012.04.011

Vuillemin, A., Ndiaye, M., Martini, R., and Davaud, E. (2011). Cement stratigraphy: image probes of cathodoluminescence facies. Swiss J. Geosci. 104, 55-66. doi: 10.1007/s00015-010-0047-8

Yao, M., Elling, F. J., Jones, C., Nomosatryo, S., Long, C. P., Crowe, S. A., et al. (2016). Heterotrophic bacteria from an extremely phosphate-poor lake have conditionally reduced phosphorus demand and utilize diverse sources of phosphorus. Environ. Microbiol. 18, 656-667. doi: 10.1111/1462-2920.13063

Zavarzina, D. G., Sokolova, T. G., Tourova, T. P., Chernyh, N. A., Kostrikina, N. A., and Bonch-Osmolovskaya, E. A. (2007). Thermincola ferriacetica sp. nov., a new anaerobic, thermophilic, facultatively chemolithoautotrophic bacterium capable of dissimilatory Fe(III) reduction. Extremophiles 11, 1-7. doi: 10.1007/s00792-006-0004-7
Zegeye, A., Bonneville, S., Benning, L. G., Sturm, A., Fowle, D. A., Jones, C. A., et al. (2012). Green rust formation controls nutrient availability in a ferruginous water column. Geology 40, 599-602. doi: 10.1130/G32 959.1

Zeng, J., Yang, L., Li, J., Liang, Y., Xiao, L., Jiang, L., et al. (2009). Vertical distribution of bacterial community structure in the sediments of two eutrophic lakes revealed by denaturing gradient gel electrophoresis (DGGE) and multivariate analysis techniques. World J. Microbiol. Biotechnol. 25, 225233. doi: 10.1007/s11274-008-9883-3

Conflict of Interest Statement: The authors declare that the research was conducted in the absence of any commercial or financial relationships that could be construed as a potential conflict of interest.

Copyright $\odot 2016$ Vuillemin, Friese, Alawi, Henny, Nomosatryo, Wagner, Crowe and Kallmeyer. This is an open-access article distributed under the terms of the Creative Commons Attribution License (CC BY). The use, distribution or reproduction in other forums is permitted, provided the original author(s) or licensor are credited and that the original publication in this journal is cited, in accordance with accepted academic practice. No use, distribution or reproduction is permitted which does not comply with these terms. 